Original paper

\title{
Textural records and geochemistry of the Kermanshah mantle peridotites (Iran): implications for the tectonic evolution of southern Neo-Tethys
}

\author{
Ali MORADPOUR, Reza ZAREI SAHAMIEH*, Ahmad AHMADI KHALAJI, Ramin SARIKHANI
}

Department of Geology, Faculty of Sciences, Lorestan University, Khorramabad-Boroujerd Road, Khoramabad, Iran; rezazareisahamieh@gmail.com

* Corresponding author

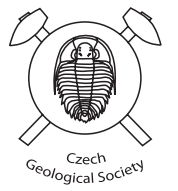

\begin{abstract}
Kermanshah Ophiolite Complex (NW Iran), located along the Main Zagros Thrust Zone, marks the ophiolitic suture between the Arabian and Sanandaj-Sirjan continental blocks. N-MORB-normalized multielement patterns and chondrite-normalized REE patterns in the Kermanshah mantle restites show depletion in incompatible elements concentrations with respect to the depleted MORB mantle (DMM). In the V vs. Yb diagram, Harsin-Sahneh-Norabad and Miyanrahan peridotites (Kermanshah Ophiolite Complex), due to their relatively low V contents, fall close to the QFM buffer. Calculated $\mathrm{TiO}_{2}$ and $\mathrm{Al}_{2} \mathrm{O}_{3}$ compositions in the parental melt that were in equilibrium with chromian spinel are consistent with supra-subduction zone-type compositions. Besides, calculated $\mathrm{FeO} / \mathrm{MgO}$ ratios in the parental melts are comparable with those in boninites from Oman ophiolites. Olivine from the peridotite restites is highly magnesian $\left(\mathrm{Fo}_{89-93}\right)$ with $\mathrm{NiO}$ contents of $0.2-0.4 \mathrm{wt}$. \%, consistent with formation in a forearc environment. This is also proven by the Cr\# and $\mathrm{Mg} \#$ values as well as $\mathrm{TiO}_{2}, \mathrm{Cr}_{2} \mathrm{O}_{3}$, and $\mathrm{Al}_{2} \mathrm{O}_{3}$ concentrations in chromian spinel of ultramafic rocks. Accordingly, petrogenetic modeling indicates that the Kermanshah ultramafic rocks may represent the residual mantle after extraction of $13-23 \%$ of boninitic-type melts. Decompression, melting and melt-rock reaction related textures are widespread in the Kermanshah mantle restites. Field relationships and geochemical evidence reveal that the studied ophiolites were a part of a rifted basin at the ocean-continent transition zone formed in the south Neo-Tethyan Ocean.
\end{abstract}

Keywords: peridotite restites, Kermanshah Ophiolite, supra-subduction zones, Neo-Tethys, Iran

Received: 16 May 2017; accepted: 20 October 2017; handling editor: E. Jelínek

\section{Introduction}

Geological evidence led Stöcklin (1968) to propose that Iran consists of continental blocks that were detached from Gondwana and collided with Eurasia during the Triassic. A new ocean, the Neo-Tethys, was created to the south and the ancient Paleo-Tethys Ocean was closed in the north. The geodynamic evolution of Neo-Tethys realm was dominated by the existence of long-lived active subduction zones to the north, beneath Eurasia, leading to detachment and northward migration of continental fragments (such as Central Iranian continental block) from the Gondwana (Agard et al. 2011). The evidence from detrital zircon ages from Shemshak Fm. (Alborz Mountains, North of Iran), located on Paleo-Tethys suture, indicates that Carnian-early Norian (early Late Triassic, roughly 222-210 Ma) was the time of Iran-Eurasia collision. This mechanism has contributed to the construction of Eurasia at the expense of Gondwana. Based on stratigraphic evidence, Neo-Tethys rifting, along the south-eastern margin of the Afro-Arabian Plate, was initiated in Early Permian. Moreover, oceanic subduction of Neo-Tethyan beneath the active margin of Central Iran has continued from the Late Triassic till the final collision of Arabia with Eurasia.
Generally, three major tectonic elements including Zagros fold-thrust belt, Sanandaj-Sirjan Zone, and Urumieh-Dokhtar magmatic arc in western and southwestern parts of Iran, are considered related to the subduction of southern Neo-Tethyan oceanic crust and the collision of the Arabian Plate with central Iran microplate. Zagros Crush Zone, extending from Turkey-Iran border to just north of Hormuz Straits, is a part of the classic Mesozoic-Cenozoic continental collision system of the Alpine-Himalayan Orogen. This system remains an active orogenic belt which contains a series of nappes of shallow and deep-water sediments and a number of ophiolites. These ophiolites, $3000 \mathrm{~km}$ long, resulted from continental collision between AfroArabia and Central Iran and have been obducted over the Arabic-Taurides Platform from Oman to northwest of Syria, Cyprus, and Antalya (Fig. 1). Cretaceous ophiolitic belt, cropping out along Main Zagros Thrust Zone in Iran, has recorded geodynamic evolution of southern Neo-Tethys Ocean located between Arabian shield (Gondwana) and Sanandaj-Sirjan continental block (Agard et al. 2011). Therefore, the geodynamic evolution of the Zagros orogenic belt, separating northern active margin of Eurasia from southern passive 


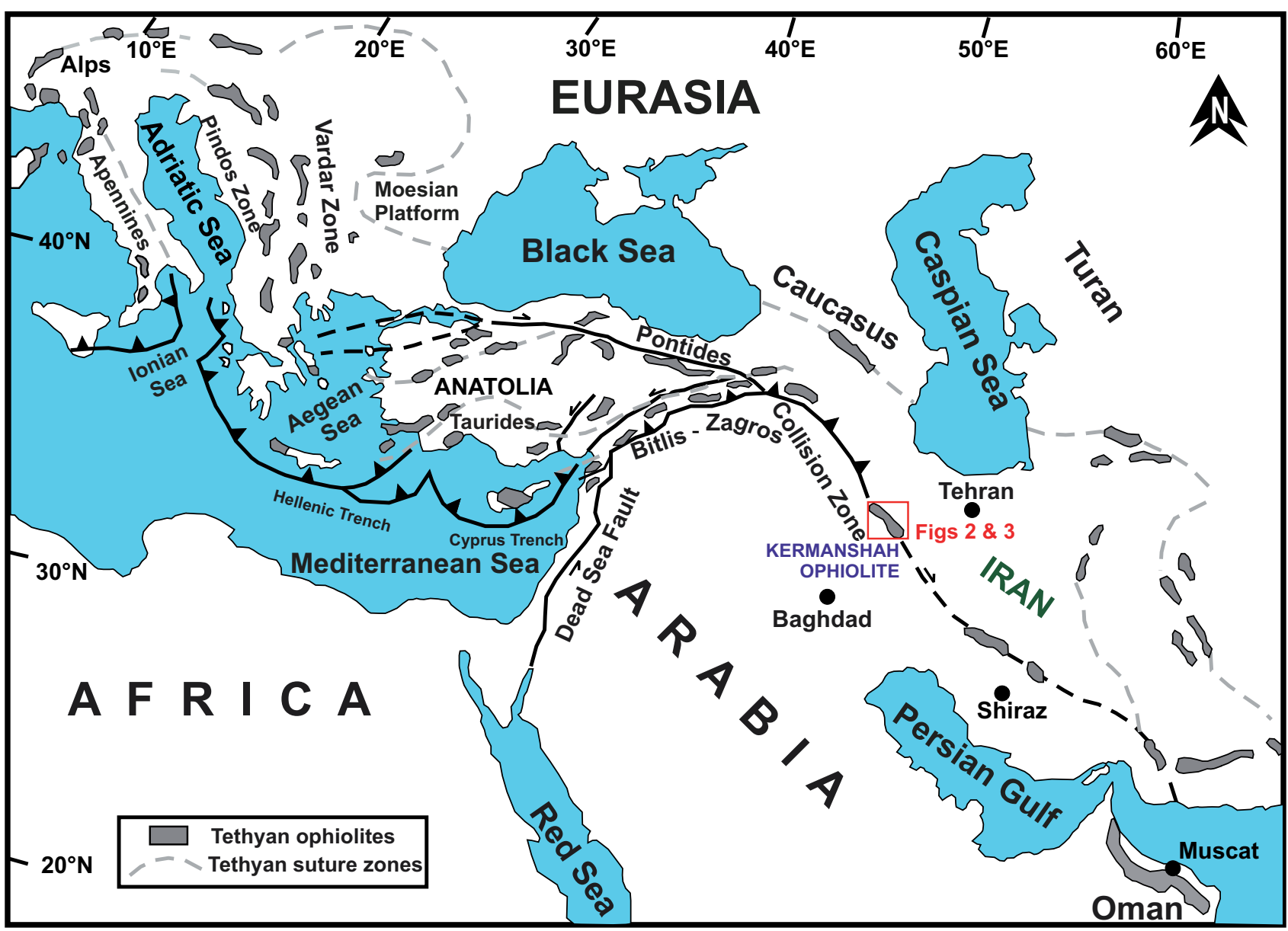

Fig. 1 Distribution of major Tethyan ophiolites and suture zones in Alpine-Himalayan orogenic system (modified from Dilek and Furnes 2011).

margin of Arabia, was mainly related to the opening and subsequent closure of the Neo-Tethys oceanic basin with a protracted history of convergence in between (Agard et al. 2011).

Zagros ophiolites can be subdivided into two belts, one south of the Main Zagros Thrust (MZT) and the other along the SW periphery of Central Iranian (Tauride) Block (Stöcklin 1968). These two parallel belts are termed the Outer Zagros Ophiolitic Belt and the Inner Zagros Ophiolitic Belt, respectively. The Outer Zagros Ophiolitic Belt includes Kermanshah, Sawlava, Neyriz, Esfandagheh, Faryab and Baft ophiolites in Iran (Rajabzadeh et al. 2013; Whitechurch et al. 2013; Allahyari et al. 2014) and Penjween ophiolites in Iraq (Aswad et al. 2011). The Outer Zagros Ophiolitic Belt is considered to be equivalent to Oman Ophiolite. The Inner Zagros Ophiolitic Belt includes Nain, Dehshir, Shahr-e-Babak and Balvard ophiolites. The Kermanshah Ophiolite is considered as a remnant of the southern branch of NeoTethyan Ocean from the Outer Zagros Ophiolitic Belt cropping out in Kermanshah Province, northwestern Iran.

As a matter of fact, Kermanshah Ophiolite differs from classical Tethyan ophiolites, such as Troodos and
Oman ophiolites that have a rather complete oceanic stratigraphy. Field evidence such as the occurrence of dismembered types of ophiolitic rocks, gabbros and serpentinized peridotites, which were locally intruded by dolerite dykes, and tectonic mutual contacts in particular, indicate that the Kermanshah Ophiolite is an ophiolitic tectonic mélange.

In recent years, most of studies on Kermanshah Ophiolite Complex have been focusing on pillow basalt, gabbro and plagiogranite in the Hasin-Sahneh area (west of Kermanshah; Saccani et al. 2013; Whitechurch et al. 2013; Zarei Sahamieh and Moradpour 2015; Ao et al. 2016). The new study of mantle peridotites can provide important information about melting processes, melt production and melt flow in the mantle wedge above the subduction zone. For this reason, the present paper focusses on the mineralogy and geochemistry of the Kermanshah mantle restites aiming to investigate petrogenetic processes, tectono-magmatic environment, melt-rock reactions and partial melting by applying textural evidence, wholerock and mineral chemistry of Harsin-Sahneh, HarsinNorabad and Miyanrahan peridotites that have not been considered yet. 


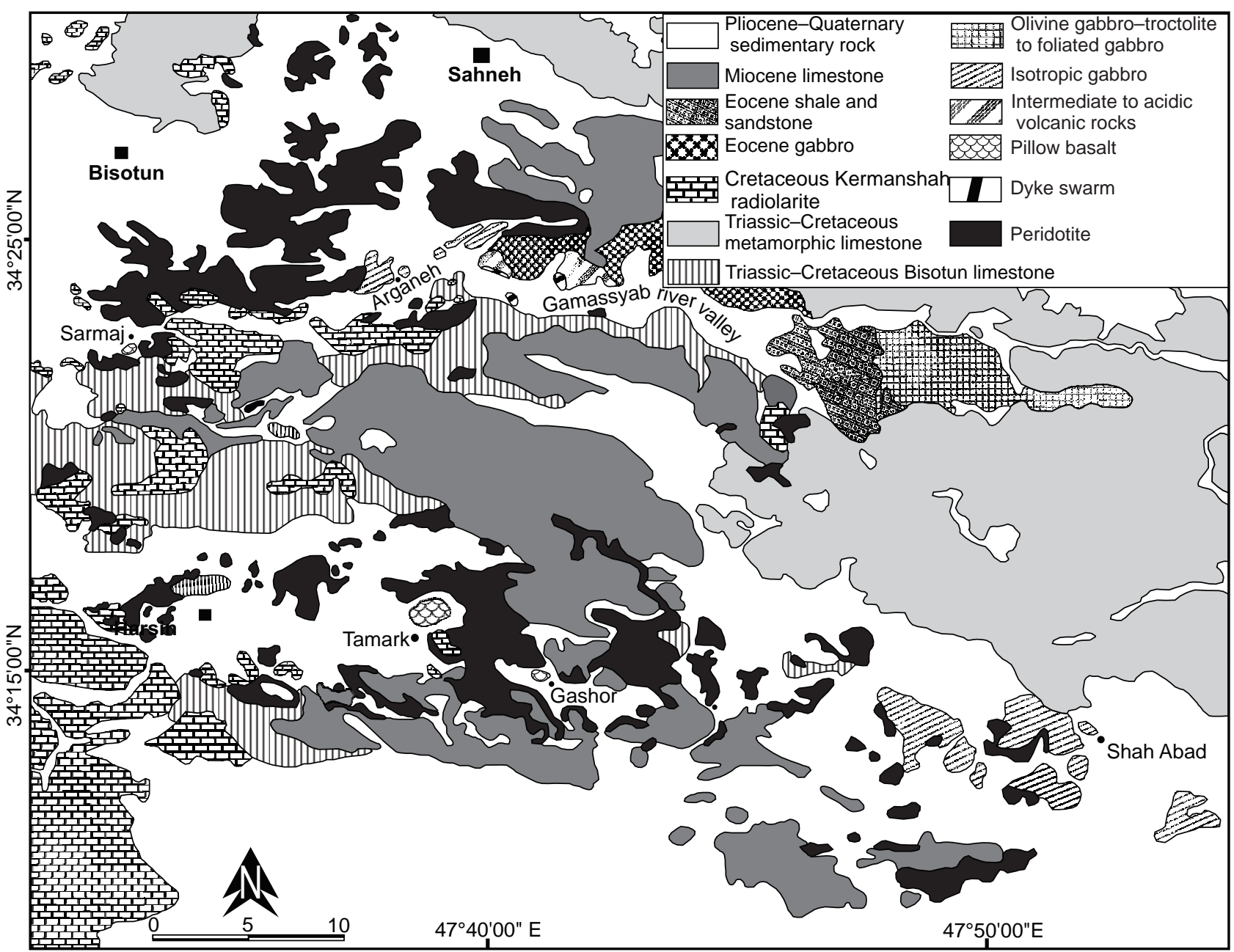

Fig. 2 Simplified geological map of Kermanshah Ophiolite in Harsin-Sahneh-Norabad area (modified from Shahidi and Nazari 1997).

\section{Geological setting}

Kermanshah Ophiolite Complex is located in the northwest part of Zagros Ophiolite Zone (Crush Zone) between Arabian Shield and Sanandaj-Sirjan Zone. There are three main structural units in Kermanshah region, from southwest to northeast, including Zagros Fold Belt, Crush Zone with ophiolites (or High Zagros), and Sanandaj-Sirjan Zone (SSZ). Kermanshah Ophiolite can be divided into two distinct parts: Harsin-Sahneh-Norabad Complex in the southeast and Miyanrahan Complex in the northwest. Harsin-Sahneh-Norabad Complex [34 $14^{\circ} 10^{\prime} \mathrm{N}$ to $34^{\circ} 30^{\prime} \mathrm{N}$ and $47^{\circ} 30^{\prime} \mathrm{E}$ to $48^{\circ} 00^{\prime} \mathrm{E}$ ] mainly consists of peridotites and gabbros intruded by dyke swarms, and covered by limestones (Bisotun Unit; Saccani et al. 2013). Moreover, pillow basalts are found in a few small outcrops in Tamark-Gashor area (Saccani et al. 2013) and at Sarmaj village (Fig. 2).

Field evidence indicates that in the south of Sahneh region (west of Arganeh village, Fig. 2), two wehrlitic dykes crop out between pegmatoid gabbro and mantle peridotite. These wehrlitic dykes have not been known from the Kermanshah Ophiolite Complex prior to the current research.

Miyanrahan Complex [34 $34^{\prime} \mathrm{N}$ to $34^{\circ} 55^{\prime} \mathrm{N}$ and $47^{\circ}$ $00^{\prime} \mathrm{E}$ to $44^{\circ} 25^{\prime} \mathrm{E}$ ] consists of several thrust sheets composed of serpentinised peridotite, lava flows and flysch (Fig. 3). Large gabbroic and dioritic intrusions crosscut Palaeocene-Eocene basalts and sediments. Marls and siliceous limestones, interbedded with basalts, have $\mathrm{Pa}-$ laeocene-Eocene ages, confirmed paleontologically (Ao et al. 2016).

In the Kermanshah area, sedimentary rocks are mainly made of deformed radiolarites, Bisotun Unit and Qom Fm. (Fig. 2). Strongly deformed radiolarites mainly crop out in the Harsin-Sahneh area. Its original substratum is considered as a continental rim basin with stratigraphic thickness of c. $500 \mathrm{~m}$ overlying the Campanian Gurpi Fm. and Maastrichtian Amiran flysch. Bisotun Unit is composed of 1500-3000 m of shallow carbonates of late Triassic to early-late Cretaceous age (Wrobel-Daveau et al. 2010). Qom Fm. is made of upper Oligocene to 


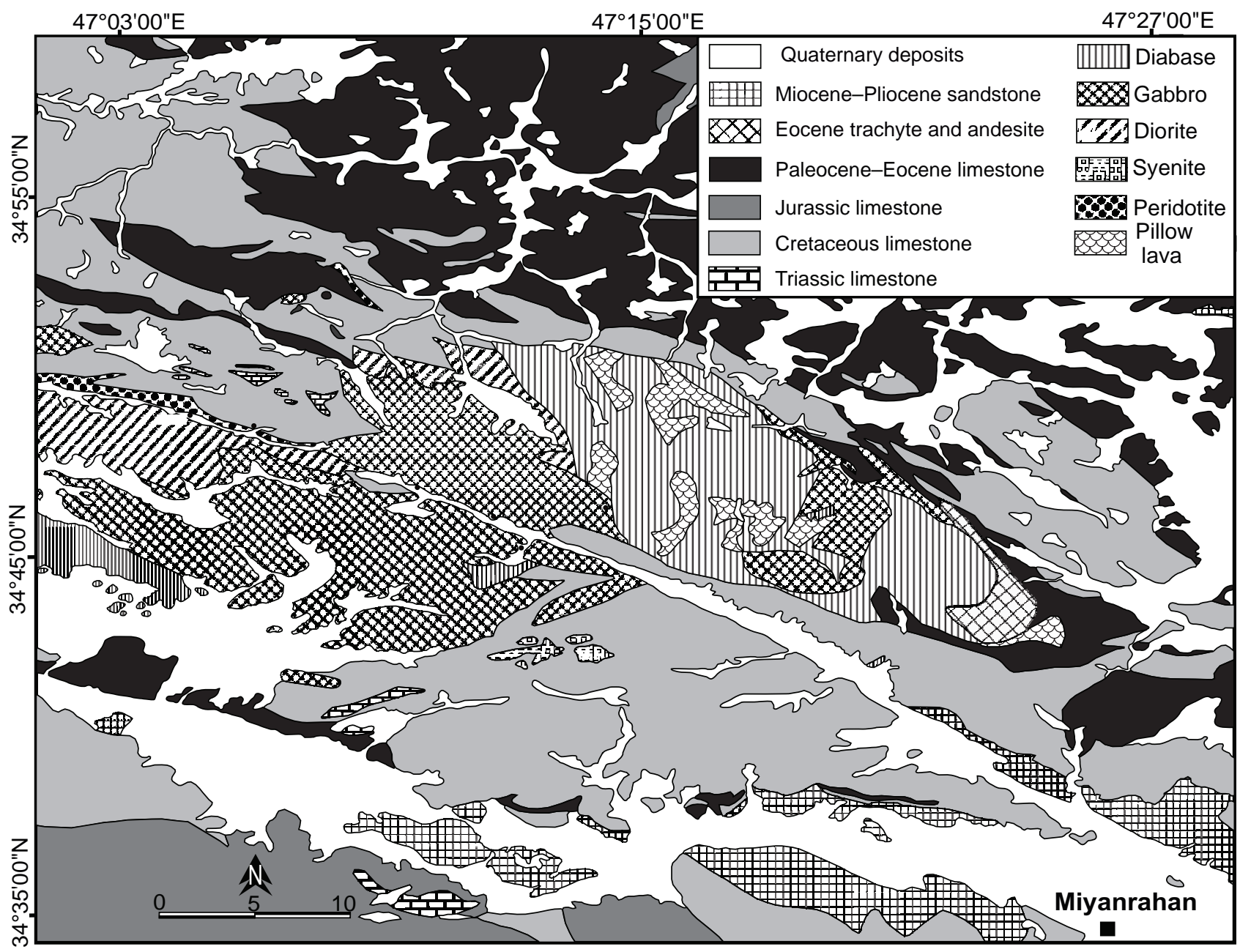

Fig. 3 Simplified geological map of Kermanshah Ophiolite in Miyanrahan area (modified from Rafia and Shahidi 1999).

lower Miocene shallow marine platform carbonates with basal conglomerates resting unconformably on the entire Kermanshah Ophiolite (Agard et al. 2011).

\section{Analytical methods}

One hundred of thin sections of Harsin-SahnehNorabad and Miyanrahan peridotites restites were studied in order to determine the dominant textures and mineral associations. The freshest samples were then selected for whole-rock chemical analyses and electronmicroprobe study.

\subsection{Mineral chemistry}

Mineral chemistry of Cr-spinel, olivine, clinopyroxene, orthopyroxene and serpentine was determined by electron-microprobe analysis (EPMA) using a Cameca SX 100 instrument at Iran Mineral Processing Research Center (IMPRC). The acceleration voltage was $15 \mathrm{keV}$, the sample current $20 \mu \mathrm{A}$ and the beam diameter $3 \mu \mathrm{m}$.
Analytical errors for major and trace elements reached 1 and $5 \%$, respectively. Instrumental calibration was made using natural and synthetic minerals as standards. The detection limit for oxide species was 100 ppm.

\subsection{Whole-rock geochemistry}

Whole-rock major- and some trace-element analyses were obtained by Inductively Coupled Plasma-Mass Spectrometry (ICP-MS) at Act Lab Analytical Laboratories Ltd., Ontario, Canada, following fusion with lithium metaborate/tetraborate (Code 4Litho). In fusion process, lithium metaborate and lithium tetraborate were mixed with the sample in graphite crucibles and then they were fused in induction furnaces at $1150^{\circ} \mathrm{C}$. The melt was immediately poured into a solution of $5 \%$ nitric acid. It was mixed continuously until it was completely dissolved ( $\sim 30 \mathrm{~min})$.

In order to determine the accurate levels of base metals such as $\mathrm{Cu}, \mathrm{Pb}, \mathrm{Zn}, \mathrm{Ni}$ and $\mathrm{Ag}, 0.25$ g of each sample were digested with four acids: hydrofluoric, followed by a mixture of nitric and perchloric acids and finally 
hydrochloric acid. Detection limits of ICP-MS in both cases lie typically between $0.04 \%$ and $0.01 \%$.

For accurate determination of As, Sb, $\mathrm{W}$ and $\mathrm{Cr}$, we used the INAA technique. Approximately $30 \mathrm{~g}$ aliquot was encapsulated and weighed in a polyethylene vial and irradiated with flux wires and an internal standard at a thermal neutron flux of $7 \times 10^{12} \mathrm{ncm}^{-2} \mathrm{~s}^{-1} \cdot{ }^{24} \mathrm{Na}$ was allowed to decay after a seven-day period. After that, the samples were counted on a high purity Ge detector with a resolution more than $1.7 \mathrm{keV}$ for the $1332 \mathrm{KeV}{ }^{60} \mathrm{Co}$. Using flux wires, calibration was done applying certified international reference materials. $10-30 \%$ of the samples were rechecked by re-measurement.

\section{Petrography}

Harzburgite makes up more than 85 vol. \% of mantle restites in Harsin-Sahneh-Norabad and c. 25 vol. \% of Miyanrahan Ophiolite Complex. Dunites and lherzolites occur as small fragments scattered in harzburgite.

Dunites consist of more than $90 \mathrm{vol}$. \% olivine and/or serpentine, with minor orthopyroxene and spinel. These rocks mostly have granular textures and show triple-point junctions between grains (Fig. 4a). Some coarse grains of olivine contain well developed fractures, undulatory extinction or kink banding due to high-T plastic mantle deformation. Serpentinization varies from weak to moderate, mostly along thin veins cutting olivine. Chrome spinels are mostly anhedral to subhedral in shape.

Harzburgite, the dominant lithology in the ophiolite massif, consists of olivine (65-80 vol. \%) and orthopyroxene (15-30 vol. \%) with < 5 vol. \% clinopyroxene. Accessory minerals are spinel, as well as secondary serpentine and magnetite. Most of these rocks are fresh, green or dark green, showing only local serpentinization along major fracture zones. Orthopyroxene porphyroclasts of harzburgites are highly variable in shape and size. Most of them are broken by irregular fractures (Fig. 4b) and form simple twins, whereas others contain sparse rounded inclusions of olivine or exsolution lamellae of clinopyroxene and orthopyroxene (Fig. 4c). Yellowish-brown to dark brown chrome spinels are mostly anhedral to subhedral in shape. In some thin sections, discontinuous chains of chrome spinels are observable in olivines (Fig. 4d).

Lherzolites occur as small fragments scattered in harzburgite. They consist of olivine (55-75 vol. \%), orthopyroxene (22-34 vol. \%) and clinopyroxene (5-10 vol. \%) with less than 5 vol. \% spinel. Olivine and orthopyroxene commonly show deformation features, such as undulose extinction and kink banding. Clinopyroxene occurs as kinked or distorted lamellae in large orthopyroxene crystals (Fig. 4e). Olivine commonly appears as large grains ( 2-4 mm) in lherzolites and clinopyroxene occurs as aggregates in lherzolites of variable size $(<1-3 \mathrm{~mm})$.

Wehrlitic dykes cropping out between pegmatoid gabbro and mantle peridotite (Fig. 4f) consist of fresh to complete serpentinized olivine (20-30 vol. \%) and clinopyroxene (70-80 vol. \%). They have poikiloblastic, granoblastic or mesh textures. Clinopyroxene is commonly 2-4 mm across, but may also form porphyroclasts up to $6 \mathrm{~mm}$ in size. Moreover, olivines are often characterized by corroded boundaries and irregular rims indicating their magmatic assimilation (Fig. 4g).

Peridotite samples are locally affected by alteration (serpentinization) in Harsin-Sahneh-Norabad and Miyanrahan ophiolite complexes. However, since mantle restites in Harsin-Sahneh region are more widespread, serpentinite masses chiefly crop out between the regions. Generally, in studied areas, serpentinization is more common in harzburgites than wehrlites, lherzolites and dunites. The degree of harzburgite serpentinization is highly variable and ranges from $40 \%$ to $100 \%$ (average $=\sim 75 \%$ ). In cases, the original rock composition is impossible to infer from petrographic observation, due to pervasive serpentinization that obscures the primary mineralogy. Serpentinized harzburgites generally display typical mesh and hourglass textures (when the serpentinization involved olivine), as well as bastitic texture (when orthopyroxene was the serpentinized mafic phase). Olivine microgranulation is frequent in majority of the samples, leaving residual anhedral and fine-grained (average diameter $=0.05 \mathrm{~mm}$ ) relict olivine. Kink banding is common and clearly visible in larger grains. Orthopyroxene is mainly found as equant subhedral grains (max. $4 \times 1 \mathrm{~mm}$ ). As a result of extensive shearing, orthopyroxene cleavage planes are often bent showing undulatory extinction.

A small outcrop of rodingitic dykes was found in southwestern part of Sahneh (northeast of Aliabad village; Fig. 2) belonging to an ultramafic sequence (Fig. 4h). These dykes are thin and white or creamy in colour. Microscopic evidence indicates that prehnite formed as a result of plagioclases alteration; tremolite or/and secondary diopside replace mainly clinopyroxene. Likewise, hydrogrossular (as the result of plagioclase alteration) has filled spaces between early clinopyroxenes. They have granoblastic texture as a result of static rodingitization (Fig. 4i).

\section{Whole-rock chemistry of peridotite}

The whole-rock major- and trace-element compositions of the studied peridotites from the Kermanshah Ophiolite are presented in Tab. 1. With a single exception, the loss on ignition (LOI) values vary in the range of 1.73-9.42 

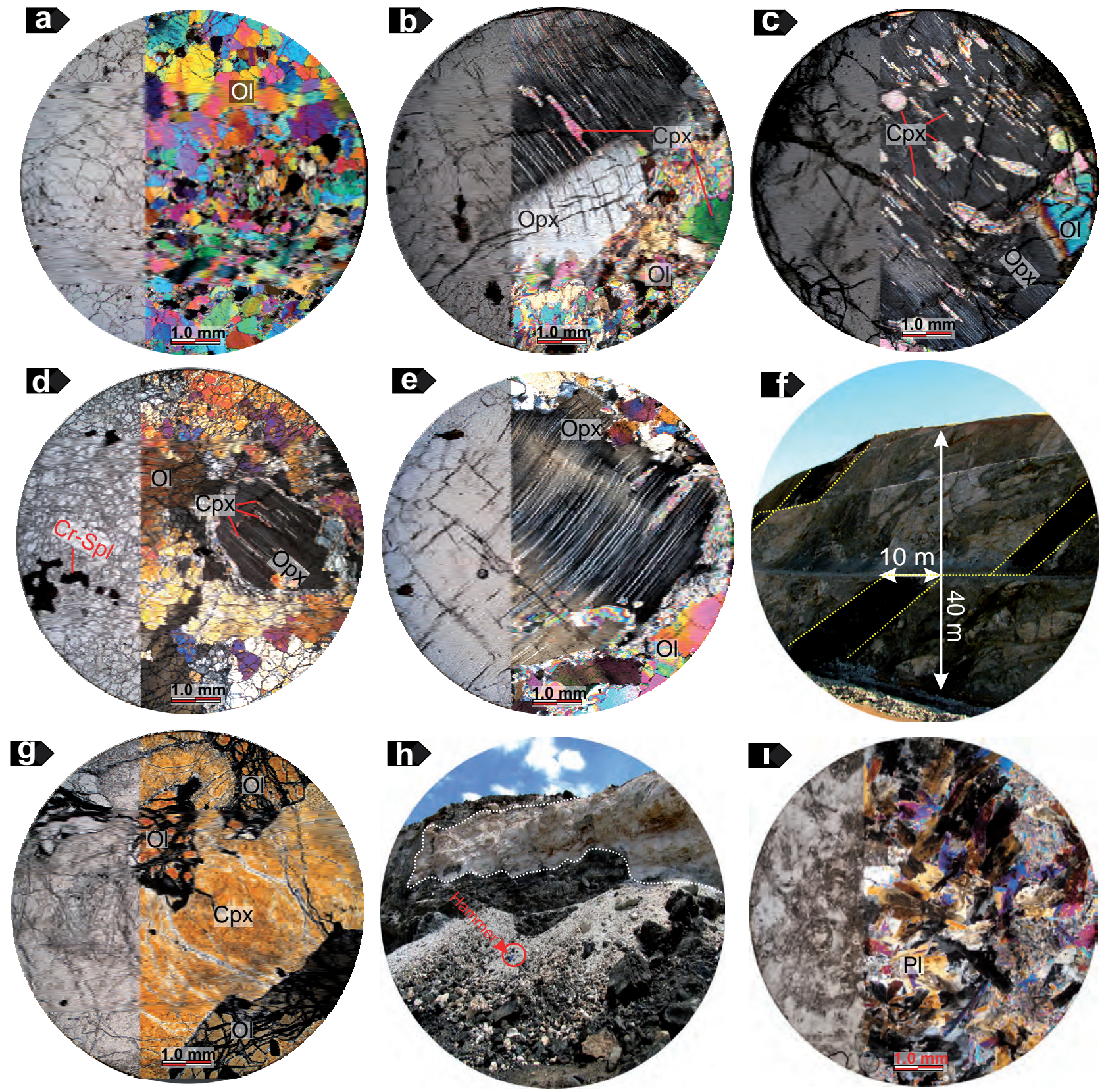

Fig. 4 Photographs of peridotites from the Kermanshah Ophiolite: a - Subhedral and euhedral olivine with triple point relationship in dunite; b - Exsolution lamellae of clinopyroxene within orthopyroxene with irregular fractures; c - Exsolution lamellae of clinopyroxene in orthopyroxene; d - Chrome spinel chain in the dunite matrix; e - Coarse orthopyroxene grains with bent lamellae of clinopyroxene; $\mathbf{f}$ - Wehrlitic dykes cutting pegmatoid gabbro and mantle peridotite; $\mathbf{g}$ - Corroded boundaries and irregular rims of olivine in clinopyroxene in wehrlites; $\mathbf{h}$ - Rodingitic dyke within the ultramafic sequence; $\mathbf{i}$ - Photomicrograph of rodingite with granoblastic texture. All photomicrographs were taken under both plane- and cross- polarized light. Ol: olivine; Opx: orthopyroxene; Cpx: clinopyroxene; Cr-Spl: chrome spinel; Srp: serpentine; Pl: plagioclase.

wt. \%, reflecting low to moderate degrees of olivine and orthopyroxene serpentinization. All ultramafic rocks have very low contents of $\mathrm{TiO}_{2}, \mathrm{P}_{2} \mathrm{O}_{5}$, $\mathrm{Zr}$ and $\mathrm{Y}$ as well as high

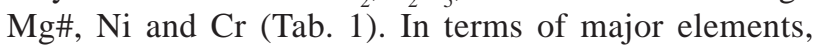
lherzolites, harzburgites, and dunites can be distinguished on the basis of their low $\mathrm{Al}_{2} \mathrm{O}_{3}$ and $\mathrm{CaO}$ contents (Tab. 1). On the other hand, Kermanshah wehrlites are enriched in components such as $\mathrm{Al}_{2} \mathrm{O}_{3}$ (4.59-4.84 wt. \%), $\mathrm{CaO}$
(5.26-5.68 wt. \%), and $\mathrm{FeO}_{\text {tot }}(11.61-11.95$ wt. \%), and depleted in MgO (27.97-28.31 wt. \%).

The mean MgO content (> 42.9 wt. \% in dunites, harzburgites and lherzolites vs. $<28.4$ wt. $\%$ in wehrlites) indicates that these rocks represent a moderately to highly depleted mantle. Accordingly, the mean of Mg\# values in dunites, harzburgites and lherzolites is 91.3 but only 82.5 in wehrlites. 

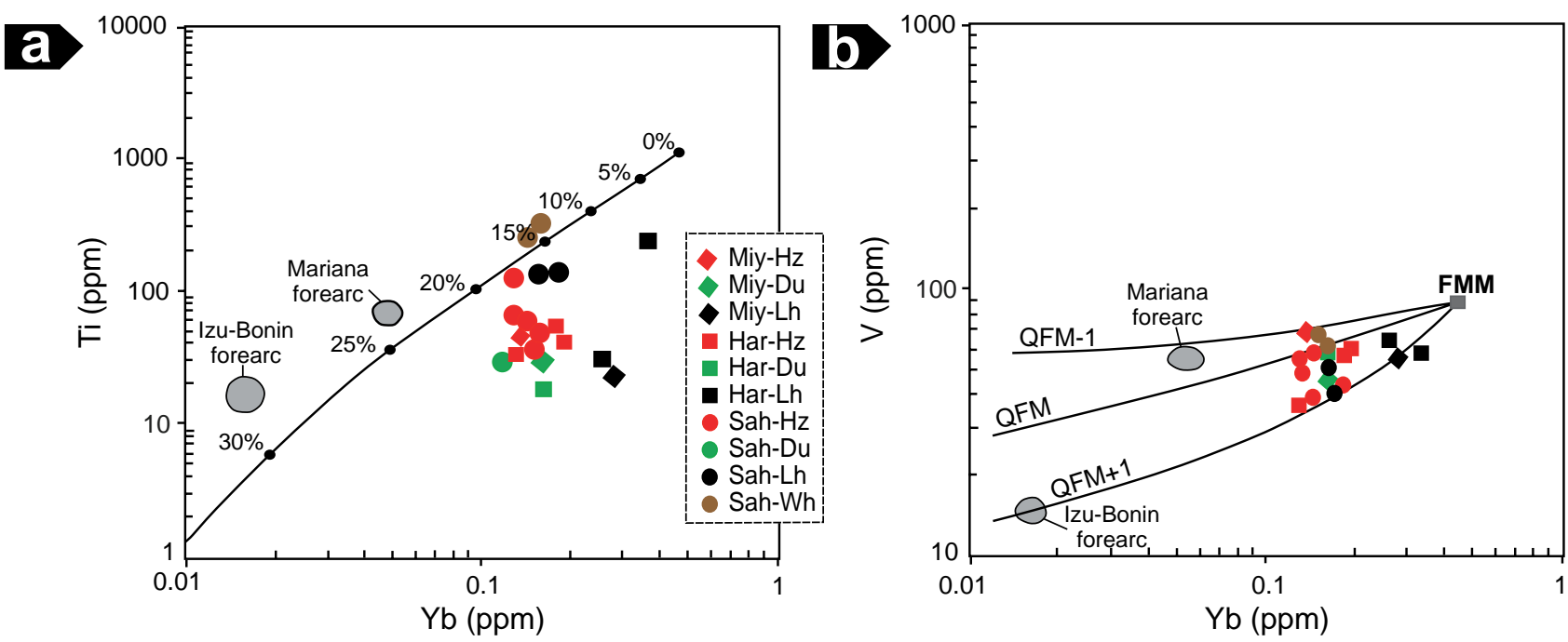

Fig. 5a - Modelled degrees of melting using Ti-Yb covariations (Pearce et al. 2000) in mantle peridotites from the Kermanshah Ophiolite. b - Oxygen fugacities estimated using the V-Yb covariations (Pearce et al. 2000). Fields for the peridotites from the Izu-Bonin-Mariana forearc, shown for comparison, are also from Pearce et al. (2000). Abbreviations, Miy: Miyanrahan; Har: Harsin; Sah: Sahneh; Hz: harzburgite; Du: dunite; Lh: 1herzolite; Wh: wehrlite. QFM: Quartz-Fayalite-Magnetite buffer; FMM: Fertile MORB Mantle.

In the plots of Ti and V vs. Yb (Fig. 5a-b), Kermanshah peridotites show variable degrees of melting and different oxygen fugacities. In the opinion of most investigators, peridotites originate as restites at sufficiently high but variable degrees of partial melting of mantle sources, usually below $50 \%$. Based on the Ti vs. Yb diagram (Fig. 5a), Kermanshah peridotites could have been derived by variable degrees of melting (20-22\%: dunites, 17-21\%: harzburgites, 15-17\%: lherzolite and 13-16\%: wehrlite).

Incompatible elements show negative covariance with $\mathrm{MgO}$ in the rocks. In contrast, as Opx and Cpx decrease (modal $\mathrm{Ol} /(\mathrm{Opx}+\mathrm{Cpx})$ ratio increases), the compatible elements (e.g., $\mathrm{Ni}$ and $\mathrm{Co}$ ) increase from lherzolite through harzburgite to dunite (i.e., with progressive melting).

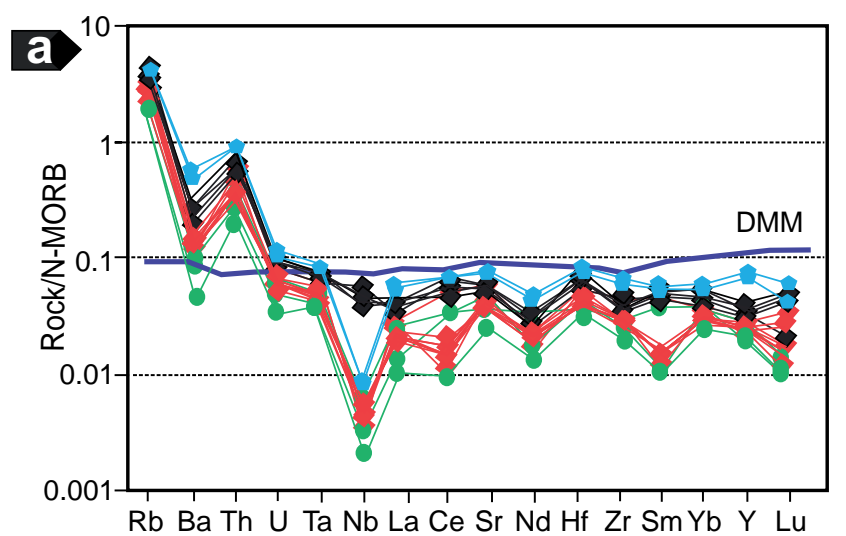

The N-MORB-normalized multielement patterns and chondrite-normalized REE patterns are shown in Fig. 6. In general, Kermanshah mantle restites show depletion in HFSE and REE concentrations with respect to the depleted MORB mantle (DMM) of Workman and Hart (2005). By contrast, wehrlites have high field strength element (HFSE) contents, higher than those of lherzolites, harzburgites and dunites (Fig. 6a).

Accordingly, wehrlites have MREE and HREE contents higher than lherzolites, harzburgites and dunites. Harzburgites and dunites are characterized by marked U-shaped chondrite-normalized patterns (Fig. 6b), that is, by a significant depletion in MREE with respect to LREE $\left(\mathrm{La}_{\mathrm{N}} / \mathrm{Sm}_{\mathrm{N}}=1.61-3.87\right)$ and $\operatorname{HREE}\left(\mathrm{Sm}_{\mathrm{N}} / \mathrm{Yb}_{\mathrm{N}}=0.13-0.51\right)$.

Regardless of the rock type, the Kermanshah mantle peridotites show REE depletion with respect to the de-

Fig. 6a - N-MORB normalized multielement patterns. b - Chondrite- normalized REE patterns for mantle peridotites from the Kermanshah Ophiolite Complex. Normalizing values are from Sun and McDonough (1989). DMM: depleted MORB mantle of Workman and Hart (2005); PM: Primitive Mantle of Sun and McDonough (1989). Patterns for Thetford wehrlite of Harnois et al. (1990) are shown for comparison. 
Tab. 1 Whole-rock chemical compositions of peridotites in Kermanshah Ophiolite Complex (major elements as wt. \% and trace elements as ppm)

\begin{tabular}{|c|c|c|c|c|c|c|c|c|c|}
\hline Area & Miy & Miy & Miy & Har & Har & Har & Har & Har & Har \\
\hline \multirow{2}{*}{ Locality } & $34^{\circ} 48^{\prime} 39^{\prime \prime} \mathrm{N}$ & $34^{\circ} 49^{\prime} 08^{\prime \prime} \mathrm{N}$ & $34^{\circ} 49^{\prime} 20^{\prime \prime} \mathrm{N}$ & $34^{\circ} 13 ' 25^{\prime \prime} \mathrm{N}$ & $34^{\circ} 14^{\prime} 32^{\prime \prime N}$ & $34^{\circ} 14^{\prime} 20^{\prime \prime} \mathrm{N}$ & $34^{\circ} 15^{\prime} 24^{\prime \prime} \mathrm{N}$ & $34^{\circ} 15^{\prime} 24^{\prime \prime N}$ & $34^{\circ} 18^{\prime} 11^{\prime \prime N}$ \\
\hline & $47^{\circ} 05^{\prime} 14^{\prime \prime E}$ & 4703'39"E & $47^{\circ} 02^{\prime} 39^{\prime \prime E}$ & $47^{\circ} 45^{\prime} 56^{\prime \prime} \mathrm{E}$ & $47^{\circ} 47^{\prime} 01^{\prime \prime E}$ & $47^{\circ} 45^{\prime} 27^{\prime \prime E}$ & $47^{\circ} 41^{\prime} 21^{\prime \prime E}$ & $47^{\circ} 41^{\prime} 21^{\prime E}$ & $47^{\circ} 48^{\prime} 01^{\prime \prime E}$ \\
\hline Sample & PR-27 & PR-28 & PR-31 & PR-21 & PR-23 & PR-22 & HZ-12 & HZ-13 & PR-25 \\
\hline Rock & $\mathrm{Hz}$ & Du & Lh & Du & $\mathrm{Hz}$ & $\mathrm{Hz}$ & $\mathrm{Hz}$ & Lh & Lh \\
\hline $\mathrm{SiO}_{2}$ & 40.28 & 39.76 & 41.43 & 41.34 & 40.43 & 39.82 & 40.30 & 39.46 & 41.65 \\
\hline $\mathrm{TiO}_{2}$ & 0.007 & 0.005 & 0.004 & 0.003 & 0.006 & 0.009 & 0.007 & 0.040 & 0.005 \\
\hline $\mathrm{Al}_{2} \mathrm{O}_{3}$ & 0.55 & 0.58 & 1.51 & 0.72 & 0.01 & 0.45 & 0.95 & 2.43 & 1.91 \\
\hline $\mathrm{FeO}^{*}$ & 9.20 & 7.66 & 8.28 & 6.98 & 6.69 & 7.81 & 6.82 & 6.88 & 6.91 \\
\hline $\mathrm{MnO}$ & 0.14 & 0.16 & 0.10 & 0.09 & 0.09 & 0.12 & 0.07 & 0.11 & 0.10 \\
\hline MgO & 41.35 & 44.63 & 42.36 & 43.50 & 45.45 & 42.95 & 43.78 & 43.42 & 42.67 \\
\hline $\mathrm{CaO}$ & 0.43 & 0.26 & 0.35 & 0.04 & 0.12 & 0.32 & 0.83 & 0.20 & 0.81 \\
\hline $\mathrm{Na}_{2} \mathrm{O}$ & n.d. & n.d. & n.d. & n.d. & n.d. & n.d. & n.d. & n.d. & n.d. \\
\hline $\mathrm{K}_{2} \mathrm{O}$ & n.d. & n.d. & n.d. & n.d. & n.d. & n.d. & n.d. & n.d. & n.d. \\
\hline $\mathrm{P}_{2} \mathrm{O}_{5}$ & 0.02 & n.d. & 0.02 & n.d. & n.d. & n.d. & n.d. & n.d. & n.d. \\
\hline L.O.I. & 7.96 & 6.50 & 5.92 & 7.10 & 6.80 & 7.65 & 6.34 & 6.76 & 5.53 \\
\hline Total & 99.94 & 99.56 & 99.97 & 99.77 & 99.60 & 99.13 & 99.10 & 99.30 & 99.59 \\
\hline Mg\# & 89.9 & 92.0 & 91.0 & 92.5 & 93.0 & 91.5 & 92.7 & 92.6 & 92.4 \\
\hline Sc & 9 & 21 & 25 & 13 & 16 & 17 & 12 & 14 & 19 \\
\hline $\mathrm{V}$ & 71 & 45 & 55 & 59 & 36 & 58 & 60 & 55 & 63 \\
\hline $\mathrm{Ba}$ & 12 & 2 & 1 & 1 & 1 & 1 & 1 & 2 & 2 \\
\hline $\mathrm{Sr}$ & 10 & 5 & 4 & 7 & 5 & 25 & 4 & 3 & 2 \\
\hline Y & 1 & 1 & 1 & 1 & 1 & 1 & 1 & 2 & 1 \\
\hline $\mathrm{Zr}$ & 2 & 2 & 2 & 3 & 3 & 2 & 3 & 2 & 2 \\
\hline $\mathrm{Cr}$ & 2325 & 2493 & 2977 & 2653 & 2442 & 2245 & 2449 & 1997 & 2878 \\
\hline Co & 112 & 100 & 86 & 92 & 96 & 103 & 91 & 93 & 88 \\
\hline $\mathrm{Ni}$ & 2674 & 2135 & 2050 & 1954 & 2227 & 1656 & 1945 & 1857 & 1846 \\
\hline $\mathrm{Cu}$ & 10 & 10 & 30 & 20 & 10 & 10 & 10 & 30 & 20 \\
\hline $\mathrm{Zn}$ & 39 & 27 & 35 & 25 & 25 & 24 & 26 & 42 & 30 \\
\hline $\mathrm{Ga}$ & 7 & 5 & 6 & 8 & 6 & 3 & 6 & 4 & 7 \\
\hline $\mathrm{Rb}$ & 2 & 3 & 4 & 2 & 6 & 4 & 3 & 4 & 2 \\
\hline $\mathrm{Nb}$ & n.d. & n.d. & n.d. & n.d. & n.d. & n.d. & n.d. & n.d. & n.d. \\
\hline $\mathrm{La}$ & 0.2 & 0.1 & 0.9 & 0.2 & 0.1 & 0.1 & 0.1 & 0.1 & 0.1 \\
\hline $\mathrm{Ce}$ & 0.2 & 0.1 & 1.3 & 0.3 & n.d. & 0.1 & 0.2 & 0.1 & 0.2 \\
\hline $\operatorname{Pr}$ & 0.05 & 0.01 & 0.17 & n.d. & 0.05 & 0.01 & 0.01 & n.d. & n.d. \\
\hline $\mathrm{Nd}$ & 0.22 & 0.13 & 0.17 & 0.15 & 0.16 & 0.16 & 0.19 & 0.18 & 0.17 \\
\hline $\mathrm{Sm}$ & 0.03 & 0.04 & 0.13 & 0.04 & 0.05 & 0.03 & 0.06 & 0.02 & 0.04 \\
\hline Eu & 0.04 & 0.01 & 0.12 & 0.01 & 0.02 & 0.02 & 0.01 & 0.03 & 0.01 \\
\hline $\mathrm{Gd}$ & 0.04 & 0.05 & 0.04 & 0.06 & 0.03 & 0.03 & 0.03 & 0.6 & 0.04 \\
\hline Tm & 0.01 & 0.01 & 0.02 & 0.01 & 0.05 & 0.01 & 0.03 & 0.02 & 0.02 \\
\hline $\mathrm{Yb}$ & 0.14 & 0.16 & 0.28 & 0.16 & 0.13 & 0.18 & 0.19 & 0.36 & 0.26 \\
\hline $\mathrm{Lu}$ & 0.01 & 0.01 & 0.01 & 0.01 & 0.02 & 0.02 & 0.01 & 0.01 & 0.02 \\
\hline Hf & 0.2 & 1.1 & 2.4 & 1.3 & n.d. & 2.1 & 1.5 & 1.2 & 1.8 \\
\hline Th & 0.1 & 0.1 & 0.1 & 0.1 & 0.1 & 0.2 & 0.2 & 0.1 & 0.1 \\
\hline
\end{tabular}

n.d: not detected; LOI: loss on ignition

$\mathrm{Mg} \#=100 \times \mathrm{Mg} /(\mathrm{Mg}+\mathrm{Fe})$

pleted MORB mantle. The REE contents in the Kermanshah wehrlite samples are lower than that in chondrite and are comparable with those in the Thetford wehrlite. The REE patterns of studied wehrlites testify to a relatively weak fractionation of these elements. Wehrlites from Kermanshah Ophiolite have a generally gentle slope in their patterns, i.e. insignificant depletion of the light compared to the heavy and middle REE $\left(\mathrm{La}_{\mathrm{N}} /\right.$ $\left.\mathrm{Yb}_{\mathrm{N}}=0.47-0.51\right)$.

\section{Mineral chemistry}

\subsection{Olivine}

Olivine compositions of Kermanshah peridotites are listed in Tab. 2. The forsterite content of olivine is mostly in the range of $\mathrm{Fo}_{86-90}[\mathrm{Fo}=\mathrm{Mg} /(\mathrm{Mg}+\mathrm{Fe})]$, averaging $\mathrm{Fo}_{90.43}$ in dunite, $\mathrm{Fo}_{90.18}$ in harzburgite, $\mathrm{Fo}_{90.14}$ in lherzolite and $\mathrm{Fo}_{86.32}$ in wehrlite. 
Tab. 1 Continued

\begin{tabular}{|c|c|c|c|c|c|c|c|c|c|c|}
\hline Area & Sah & Sah & Sah & Sah & Sah & Sah & Sah & Sah & Sah & Sah \\
\hline \multirow{2}{*}{ Locality } & $34^{\circ} 28^{\prime} 07^{\prime \prime N}$ & $34^{\circ} 26^{\prime} 00^{\prime \prime N}$ & $34^{\circ} 26^{\prime} 23^{\prime \prime} \mathrm{N}$ & $34^{\circ} 28^{\prime} 14^{\prime \prime} \mathrm{N}$ & $34^{\circ} 26^{\prime} 17^{\prime \prime N}$ & $34^{\circ} 23^{\prime} 44^{\prime \prime N}$ & $34^{\circ} 23^{\prime} 43^{\prime \prime} \mathrm{N}$ & $34^{\circ} 25^{\prime} 47^{\prime \prime N}$ & $34^{\circ} 25^{\prime} 31^{\prime \prime N}$ & $34^{\circ} 27^{\prime} 02^{\prime \prime} \mathrm{N}$ \\
\hline & $47^{\circ} 36^{\prime} 52^{\prime \prime E}$ & $47^{\circ} 36^{\prime} 08^{\prime \prime} \mathrm{E}$ & $47^{\circ} 39^{\prime} 47^{\prime \prime E}$ & $47^{\circ} 37^{\prime} 18 " \mathrm{E}$ & $47^{\circ} 39^{\prime} 39^{\prime \prime E}$ & $47^{\circ} 38^{\prime} 25^{\prime \prime} \mathrm{E}$ & $47^{\circ} 38^{\prime} 28^{\prime \prime} \mathrm{E}$ & $47^{\circ} 36^{\prime} 35^{\prime \prime E}$ & $47^{\circ} 36^{\prime} 37^{\prime \prime E}$ & $47^{\circ} 39^{\prime} 32^{\prime \prime} \mathrm{E}$ \\
\hline Sample & HZ-5 & PR-10 & PR-16 & HZ-6 & PR-17 & PR-7-1 & PR-7-2 & PR- 11 & PR- 15 & Pr-9 \\
\hline Rock & $\mathrm{Hz}$ & $\mathrm{Hz}$ & $\mathrm{Hz}$ & $\mathrm{Hz}$ & $\mathrm{Hz}$ & Wh & Wh & Lh & Lh & $\mathrm{Du}$ \\
\hline$\overline{\mathrm{SiO}_{2}}$ & 41.58 & 44.52 & 44.75 & 41.11 & 43.28 & 39.58 & 39.02 & 39.35 & 40.73 & 38.64 \\
\hline $\mathrm{TiO}_{2}$ & 0.006 & 0.009 & 0.021 & 0.010 & 0.011 & 0.048 & 0.043 & 0.023 & 0.024 & 0.005 \\
\hline $\mathrm{Al}_{2} \mathrm{O}_{3}$ & 0.50 & 0.83 & 2.06 & 0.22 & 0.69 & 4.59 & 4.84 & 1.12 & 1.08 & 0.12 \\
\hline $\mathrm{FeO}^{*}$ & 8.41 & 8.86 & 9.09 & 8.54 & 7.85 & 11.61 & 11.95 & 9.06 & 8.85 & 8.53 \\
\hline $\mathrm{MnO}$ & 0.11 & 0.11 & 0.13 & 0.12 & 0.12 & 0.14 & 0.15 & 0.14 & 0.11 & 0.11 \\
\hline $\mathrm{MgO}$ & 41.73 & 42.09 & 41.92 & 43.24 & 42.58 & 28.31 & 27.97 & 39.55 & 40.44 & 47.66 \\
\hline $\mathrm{CaO}$ & 0.74 & 0.95 & 2.22 & 0.79 & 0.83 & 5.26 & 5.68 & 0.97 & 1.32 & 0.15 \\
\hline $\mathrm{Na}_{2} \mathrm{O}$ & 0.02 & 0.04 & 0.08 & 0.02 & 0.03 & 0.08 & 0.09 & 0.07 & 0.04 & 0.02 \\
\hline $\mathrm{K}_{2} \mathrm{O}$ & n.d. & n.d. & n.d. & n.d. & n.d. & n.d. & n.d. & n.d. & n.d. & n.d. \\
\hline $\mathrm{P}_{2} \mathrm{O}_{5}$ & n.d. & n.d. & n.d. & n.d. & n.d. & n.d. & n.d. & n.d. & n.d. & n.d. \\
\hline L.O.I. & 6.01 & 1.73 & 0.00 & 5.54 & 4.39 & 9.42 & 9.29 & 8.96 & 6.83 & 4.35 \\
\hline Total & 99.11 & 99.14 & 100.17 & 99.59 & 99.78 & 99.04 & 99.03 & 99.24 & 99.43 & 99.59 \\
\hline Mg\# & 90.7 & 90.4 & 90.1 & 91.0 & 91.5 & 82.8 & 82.2 & 89.6 & 90.0 & 91.7 \\
\hline Sc & 9 & 10 & 13 & 7 & 12 & 21 & 25 & 6 & 8 & 2 \\
\hline $\mathrm{V}$ & 63 & 40 & 58 & 42 & 50 & 64 & 69 & 40 & 52 & 10 \\
\hline $\mathrm{Ba}$ & 3 & 2 & 4 & 4 & 4 & 2 & 2 & 2 & 3 & 2 \\
\hline $\mathrm{Sr}$ & 4 & 5 & 7 & 3 & 3 & 8 & 9 & 3 & 4 & 10 \\
\hline $\mathrm{Y}$ & 1 & 1 & 1 & 1 & 1 & 2 & 2 & 2 & 5 & 2 \\
\hline $\mathrm{Zr}$ & 4 & 8 & 3 & 6 & 3 & 7 & 10 & 3 & 6 & 2 \\
\hline $\mathrm{Cr}$ & 2621 & 2820 & 2962 & 2797 & 2717 & 2315 & 2303 & 2189 & 2657 & 2959 \\
\hline Co & 108 & 112 & 110 & 112 & 113 & 114 & 116 & 100 & 95 & 113 \\
\hline $\mathrm{Ni}$ & 2323 & 2358 & 2322 & 2381 & 2290 & 1024 & 1197 & 2455 & 2362 & 2981 \\
\hline $\mathrm{Cu}$ & 40 & 10 & 50 & 30 & 30 & 10 & 10 & 20 & 30 & 10 \\
\hline Zn & 51 & 53 & 54 & 58 & 43 & 47 & 45 & 43 & 46 & 13 \\
\hline Ga & 1 & 1 & 2 & 2 & 1 & 3 & 3 & 1 & 3 & 2 \\
\hline $\mathrm{Rb}$ & 4 & 4 & 2 & 4 & 2 & 2 & 2 & 2 & 3 & 2 \\
\hline $\mathrm{Nb}$ & n.d. & n.d. & n.d. & 1 & 1 & n.d. & 1 & n.d. & 1 & 2 \\
\hline $\mathrm{La}$ & 0.1 & 0.3 & 0.1 & 0.2 & 0.1 & 0.1 & 0.1 & 0.1 & 0.1 & 0.1 \\
\hline $\mathrm{Ce}$ & 0.2 & 0.7 & 0.3 & 0.4 & 0.3 & 0.3 & 0.4 & 0.2 & 0.2 & 0.4 \\
\hline Pr & 0.01 & 0.07 & n.d. & 0.06 & 0.07 & 0.01 & 0.06 & 0.05 & 0.05 & n.d. \\
\hline $\mathrm{Nd}$ & 0.16 & 0.45 & 0.14 & 0.16 & 0.17 & 0.34 & 0.24 & 0.14 & 0.25 & 0.25 \\
\hline $\mathrm{Sm}$ & 0.02 & 0.05 & 0.06 & 0.03 & 0.04 & 0.05 & 0.03 & 0.03 & 0.06 & 0.02 \\
\hline $\mathrm{Eu}$ & 0.01 & 0.01 & 0.03 & 0.01 & 0.01 & 0.01 & 0.00 & 0.01 & 0.02 & 0.01 \\
\hline Gd & 0.07 & 0.03 & 0.02 & 0.05 & 0.04 & 0.20 & 0.20 & 0.10 & 0.10 & 0.05 \\
\hline $\mathrm{Tm}$ & 0.01 & 0.03 & 0.01 & 0.02 & 0.02 & 0.01 & 0.03 & 0.02 & 0.02 & 0.01 \\
\hline $\mathrm{Yb}$ & 0.15 & 0.14 & 0.13 & 0.18 & 0.13 & 0.15 & 0.14 & 0.18 & 0.16 & 0.12 \\
\hline $\mathrm{Lu}$ & 0.01 & 0.01 & 0.03 & 0.01 & 0.02 & 0.01 & 0.02 & 0.01 & 0.03 & 0.02 \\
\hline Hf & 0.2 & 0.2 & n.d. & 0.2 & 0.2 & 0.2 & 0.2 & 0.2 & 0.2 & 0.2 \\
\hline Th & 0.1 & 0.1 & 0.1 & 0.1 & 0.3 & 0.1 & 0.1 & 0.1 & 0.1 & 0.1 \\
\hline
\end{tabular}

Area: Miy: Miyanrahan, Har: Harsin, Sah: Sahneh

Rock type: Hz: harzburgite, Du: dunite, Lh: lherzolite, Wh: wehrlite

As indicated, the olivine becomes slightly less magnesian from dunite to lherzolite. The plot of $\mathrm{Mg} /(\mathrm{Mg}+$ $\left.\mathrm{Fe}^{2+}\right)$ vs. $\mathrm{Fe}^{2+} /\left(\mathrm{Fe}^{2+}+\mathrm{Mg}\right)$ indicates that olivine in dunites, harzburgites and lherzolites is forsterite and exhibits chrysolite nature in wehrlite (Fig. 7a). The $\mathrm{NiO}, \mathrm{TiO}_{2}$ and $\mathrm{MgO}$ contents of olivine in lherzolites, harzburgites and dunites are $0.02-0.39$ wt. \%, 0.0-0.02 wt. \% and 46.45-51.15 wt. \% respectively. Compared to dunites, harzburgites, and lherzolites, olivine in wehrlites is enriched in $\mathrm{FeO}_{\text {tot }}$ (11.49-15.31 wt. \%), and depleted in MgO (43.47- 47.22 wt. \%).

\subsection{Orthopyroxene}

Representative analyses of orthopyroxene from mantle peridotites are presented in Tab. 3. The orthopyroxene is generally unzoned and, according to the classification 


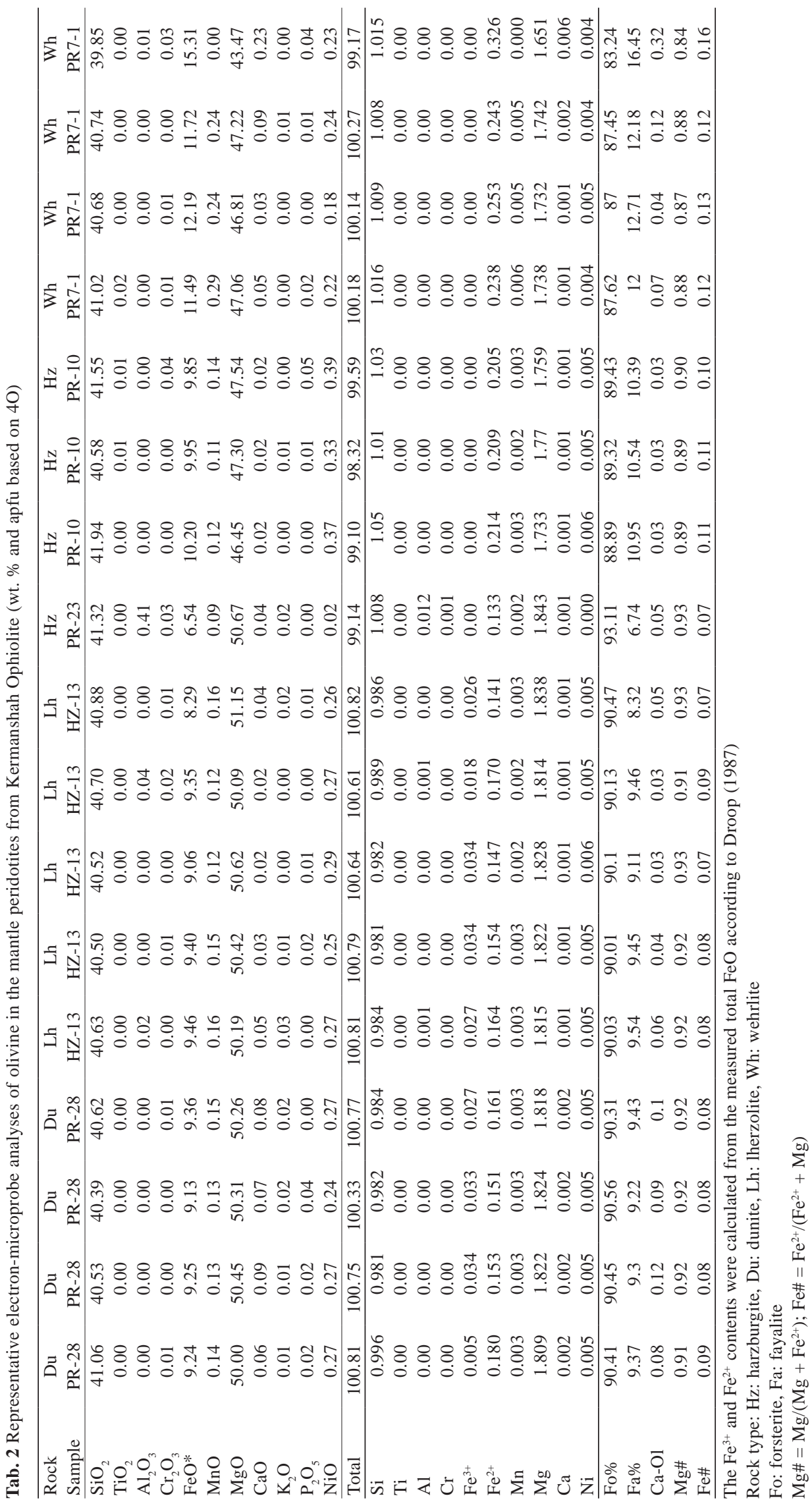

of Morimoto (1989), plots in enstatite field (Fig. 7b). The average $\mathrm{Mg} \#[100 \times \mathrm{Mg}$ / $(\mathrm{Mg}+\mathrm{Fe})]$ of orthopyroxene is 0.95 which is considered higher than average $\mathrm{Mg \#}$ of olivine (90), indicating that the distribution of $\mathrm{Mg}$ and $\mathrm{Fe}$ between olivine and orthopyroxene phases was governed by chemical equilibrium.

\subsection{Clinopyroxene}

Table 4 shows the clinopyroxene compositions from Kermanshah peridotites. All clinopyroxenes in mantle peridotites are unzoned. Besides, the clinopyroxenes classification (Morimoto 1989) indicates that clinopyroxenes in harzburgites and lherzolites are mainly diopside. Moreover, they are mainly placed in the augite field in wehrlites (Fig. 7c). The average composition of $\mathrm{Al}_{2} \mathrm{O}_{3}$ in clinopyroxene from harzburgite is $2.67 \mathrm{wt}$ \%, 5.88 wt. \% in lherzolite and 5.53 wt. \% in wehrlite with Mg\# ranging 0.90-0.99 in lherzolite, 0.92-0.98 in harzburgite and $0.88-0.95$ in wehrlite.

Comparison of clinopyroxene chemistries worldwide indicates that its $\mathrm{Na}_{2} \mathrm{O}$ contents in wehrlitic rocks are higher than those in harzburgites and lherzolites. As Mg\# decreases, $\mathrm{TiO}_{2}$ content in clinopyroxenes from peridotites increases gradually, while $\mathrm{Na}_{2} \mathrm{O}$ and $\mathrm{Al}_{2} \mathrm{O}_{3}$ contents show a sharp increase. According to Pearce and Norry (1979), the Ti content in clinopyroxenes reflects the degree of depletion of the mantle source, as well as the Ti activity of the parental magma that generated the in- 


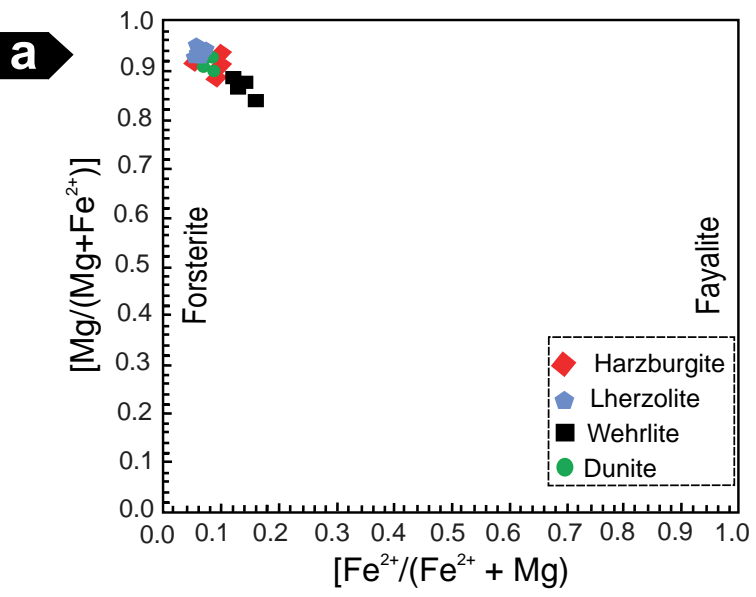

C

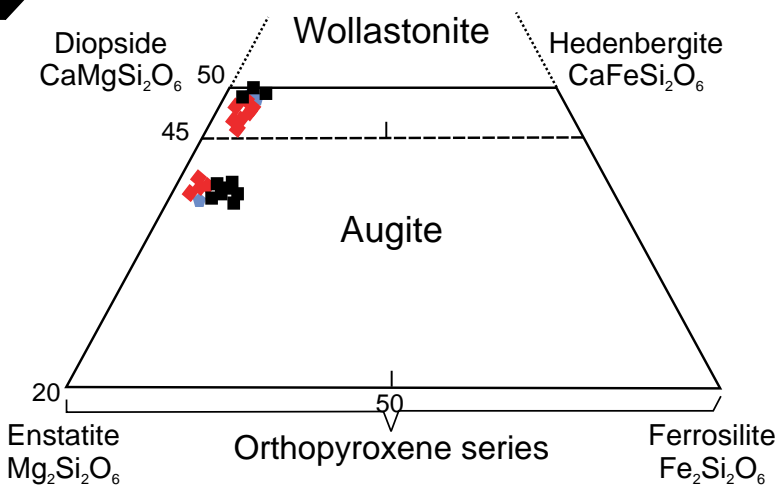

b

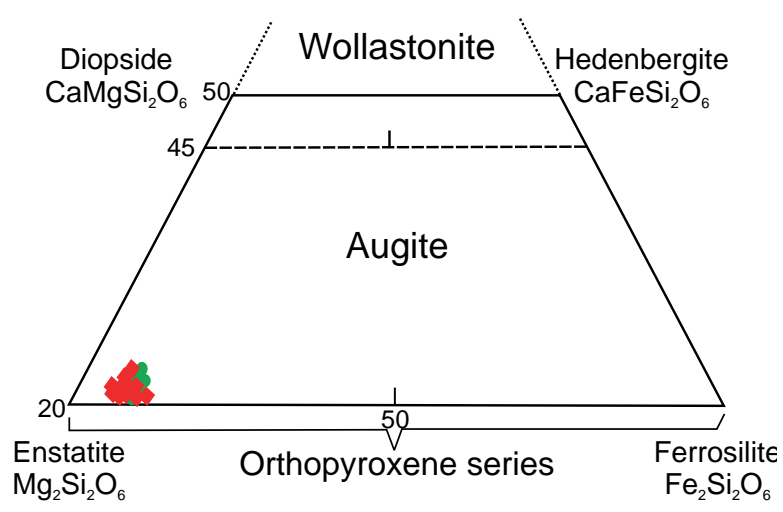

d

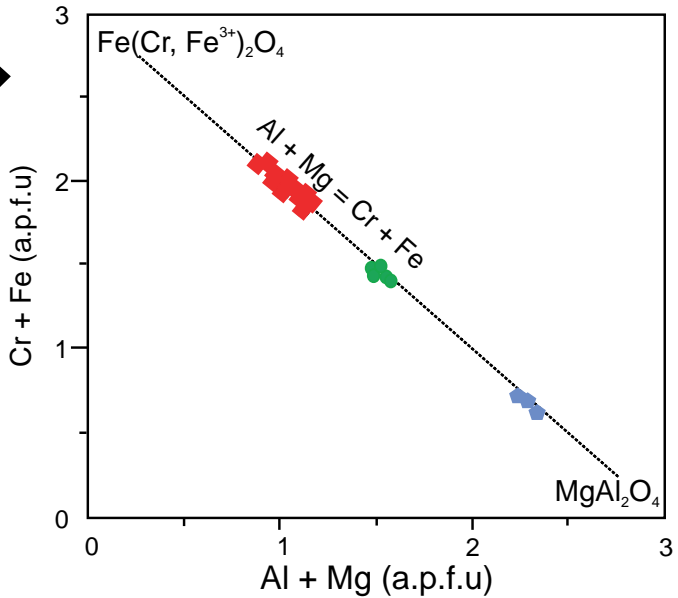

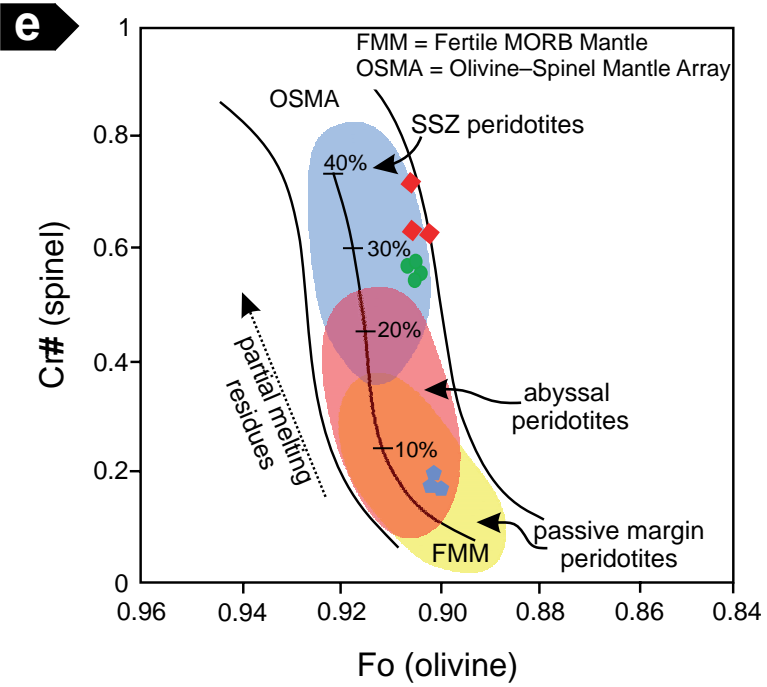

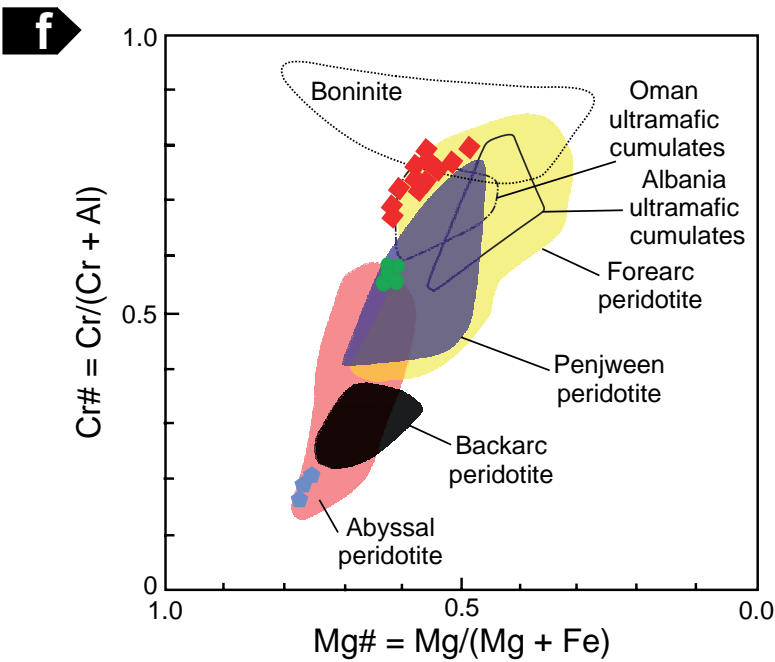

Fig. 7 Chemistry of minerals of mantle peridotites from the Kermanshah Ophiolite Complex: a - Mg\# vs. Fe\# diagram for olivines (Deer et al. 1992). b-c - Pyroxene quadrilateral diagram (Morimoto 1989) showing the composition of orthopyroxene and clinopyroxene; d - Cation plot of $\mathrm{Cr}+\mathrm{Fe}$ vs. Al + Mg for chromian spinels; the diagonal line represents a 1:1 replacement; e - Plot of Cr\# (spinel) vs. Fo (olivine) after Pearce et al. (2000), showing the fields of abyssal peridotite after Dick and Bullen (1984), supra-subduction zone (SSZ) peridotites after Pearce et al. (2000). FMM = Fertile MORB Mantle. The olivine-spinel mantle array (OSMA) and melting trend are from Arai (1994); f - Cr\# vs. Mg\# diagram for chromian spinels (modified from Dick and Bullen 1984) with compositional fields for spinels in boninites (Barnes and Roeder 2001), forearc and back-arc peridotites (Kamenetsky et al. 2001) and abyssal peridotites (Dick and Bullen 1984); Penjween peridotites (Aswad et al. 2011) are shown for comparison. 


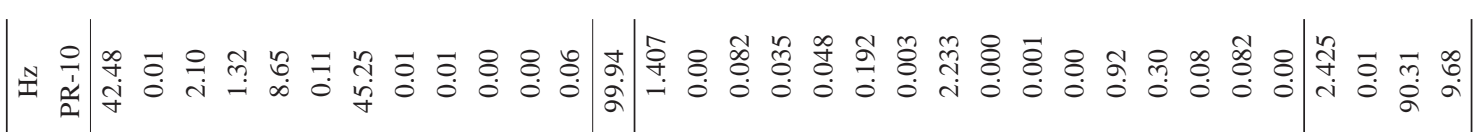

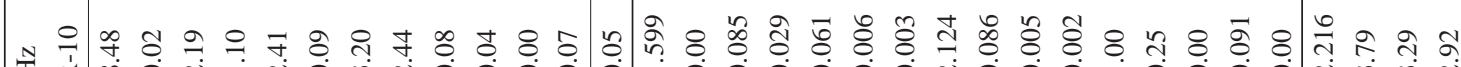

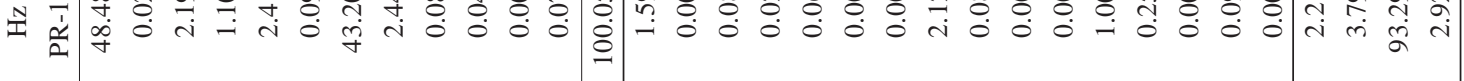

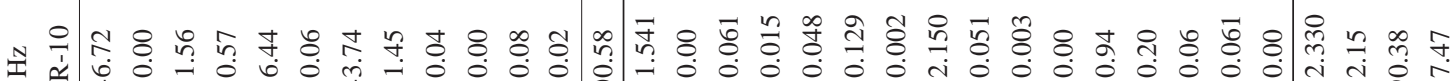

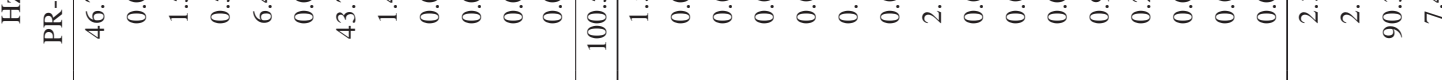

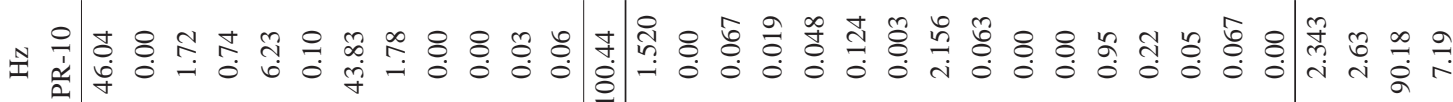

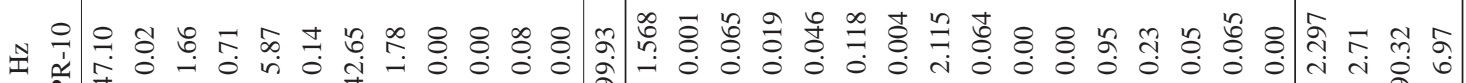

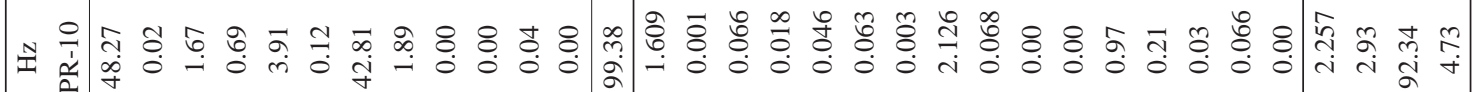
서

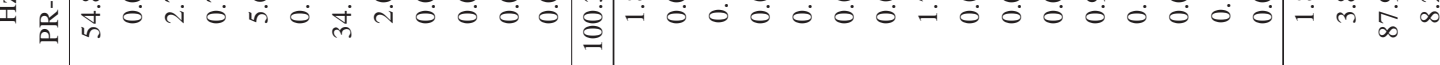

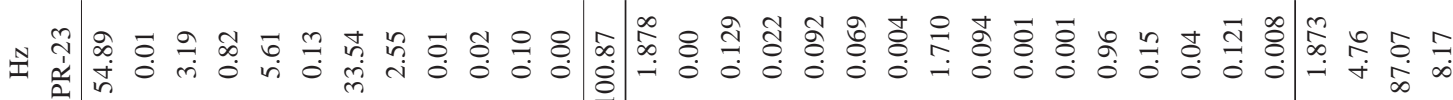

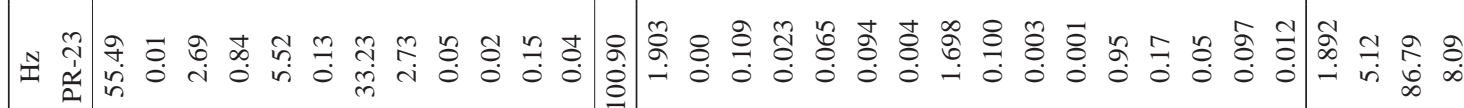
소 సิ

ก ๆ

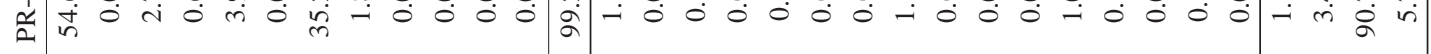
ป

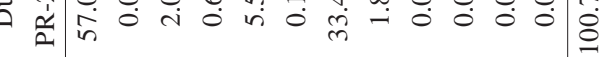

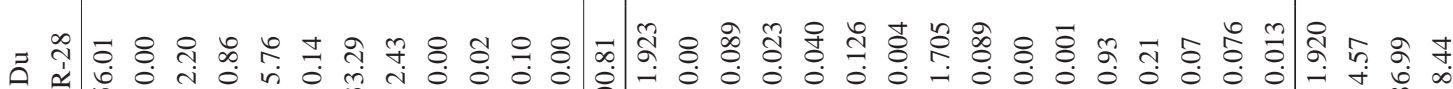
จ

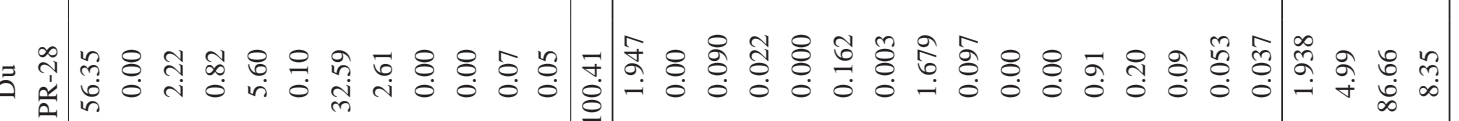
ๆ

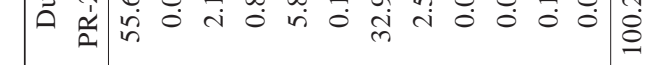

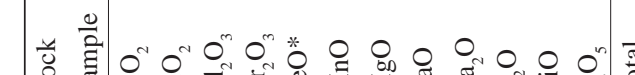

$0^{n} \mid$

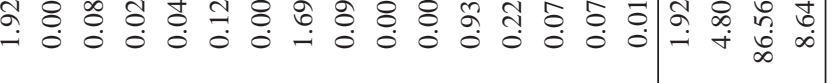
列 
Kermanshah peridotite and evolution of southern Neo-Tethys

Tab. 4 Representative electron-microprobe analyses of clinopyroxene (wt. \% and apfu based on 6O)

\begin{tabular}{|c|c|c|c|c|c|c|c|c|c|c|c|c|c|c|}
\hline Rock & Lh & Lh & Lh & $\mathrm{Hz}$ & $\mathrm{Hz}$ & $\mathrm{Hz}$ & $\mathrm{Hz}$ & $\mathrm{Hz}$ & $\mathrm{Hz}$ & $\mathrm{Hz}$ & $\mathrm{Hz}$ & $\mathrm{Hz}$ & $\mathrm{Hz}$ & $\mathrm{Hz}$ \\
\hline Sample & HZ-13 & HZ-13 & HZ-13 & PR-23 & PR-23 & PR-23 & PR-23 & PR-23 & PR-23 & PR-23 & PR-10 & PR-10 & PR-10 & PR-10 \\
\hline $\mathrm{SiO}_{2}$ & 51.38 & 51.57 & 53.08 & 53.31 & 53.68 & 54.18 & 54.16 & 55.05 & 52.84 & 52.93 & 47.83 & 48.89 & 48.71 & 49.72 \\
\hline $\mathrm{TiO}_{2}$ & 0.00 & 0.00 & 0.00 & 0.04 & 0.03 & 0.02 & 0.03 & 0.01 & 0.02 & 0.01 & 0.02 & 0.03 & 0.02 & 0.03 \\
\hline $\mathrm{Al}_{2} \mathrm{O}_{3}$ & 5.47 & 6.09 & 6.09 & 3.66 & 3.28 & 2.97 & 3.27 & 1.5 & 3.4 & 3.58 & 1.97 & 2.04 & 2.07 & 1.69 \\
\hline $\mathrm{Cr}_{2} \mathrm{O}_{3}$ & 1.26 & 1.27 & 1.22 & 1.22 & 1.15 & 1.05 & 1.23 & 0.59 & 0.97 & 1.01 & 0.9 & 1.02 & 1 & 0.76 \\
\hline $\mathrm{FeO}^{*}$ & 2.53 & 2.87 & 2.99 & 2.44 & 2.32 & 2.08 & 2.7 & 1.81 & 2.73 & 2.19 & 2.7 & 2.59 & 3.3 & 2.62 \\
\hline MgO & 16.46 & 15.98 & 22.3 & 16.53 & 16.95 & 16.4 & 17.57 & 18.41 & 17.05 & 18.17 & 27.12 & 26.07 & 25.65 & 25.89 \\
\hline $\mathrm{CaO}$ & 23.15 & 22.3 & 12.74 & 22.72 & 23.01 & 23.71 & 21.66 & 23.22 & 21.82 & 21.65 & 19.86 & 19.7 & 19.62 & 20.03 \\
\hline $\mathrm{Na}_{2} \mathrm{O}$ & 0.47 & 0.34 & 1.25 & 0.00 & 0.01 & 0.00 & 0.00 & 0.03 & 0.14 & 0.03 & 0.01 & 0.09 & 0.01 & 0.01 \\
\hline $\mathrm{K}_{2} \mathrm{O}$ & 0.02 & 0.00 & 0.06 & 0.01 & 0.01 & 0.01 & 0.00 & 0.01 & 0.02 & 0.02 & 0.00 & 0.00 & 0.00 & 0.00 \\
\hline $\mathrm{NiO}$ & 0.04 & 0.04 & 0.05 & 0.4 & 0.33 & 0.33 & 0.24 & 0.04 & 0.03 & 0.04 & 0.02 & 0.02 & 0.00 & 0.03 \\
\hline Total & 100.80 & 100.56 & 99.81 & 100.39 & 100.85 & 100.84 & 100.93 & 100.70 & 99.11 & 99.69 & 100.50 & 100.53 & 100.43 & 100.90 \\
\hline $\mathrm{Ti}$ & 0.00 & 0.00 & 0.00 & 0.001 & 0.001 & 0.001 & 0.001 & 0.00 & 0.001 & 0.00 & 0.00 & 0.00 & 0.00 & 0.00 \\
\hline $\mathrm{Al}$ & 0.232 & 0.260 & 0.254 & 0.157 & 0.140 & 0.127 & 0.139 & 0.064 & 0.147 & 0.153 & 0.081 & 0.084 & 0.086 & 0.069 \\
\hline $\mathrm{Cr}$ & 0.036 & 0.036 & 0.034 & 0.035 & 0.033 & 0.030 & 0.035 & 0.017 & 0.028 & 0.029 & & 0.028 & 0.028 & 0.021 \\
\hline $\mathrm{Fe}^{3+}$ & 0.070 & 0.00 & 0.042 & 0.00 & 0.00 & 0.00 & 0.00 & 0.00 & 0.00 & 0.00 & 0.056 & 0.060 & 0.057 & 0.048 \\
\hline $\mathrm{Fe}^{2+}$ & 0.006 & 0.087 & 0.046 & 0.074 & 0.070 & 0.063 & 0.082 & 0.054 & 0.084 & 0.066 & 0.023 & 0.015 & 0.039 & 0.029 \\
\hline $\mathrm{Mn}$ & 0.002 & 0.003 & 0.001 & 0.002 & 0.002 & 0.003 & 0.002 & 0.002 & 0.003 & 0.002 & 0.002 & 0.002 & 0.001 & 0.003 \\
\hline Mg & 0.882 & 0.861 & 1.176 & 0.898 & 0.915 & 0.887 & 0.946 & 0.987 & 0.932 & 0.983 & 1.407 & 1.357 & 1.341 & 1.346 \\
\hline $\mathrm{Ca}$ & 0.892 & 0.864 & 0.483 & 0.888 & 0.893 & 0.922 & 0.838 & 0.895 & 0.857 & 0.842 & & 0.737 & 0.737 & 0.749 \\
\hline $\mathrm{Na}$ & 0.033 & 0.024 & 0.086 & 0.00 & 0.001 & 0.00 & 0.00 & 0.002 & 0.010 & 0.002 & 0.001 & 0.006 & 0.001 & 0.001 \\
\hline $\mathrm{K}$ & 0.001 & 0.00 & 0.003 & 0.00 & 0.00 & 0.00 & 0.00 & 0.00 & 0.001 & 0.001 & 0.00 & 0.00 & 0.00 & 0.00 \\
\hline Mg\# & 0.993 & 0.908 & 0.962 & 0.924 & 0.929 & 0.934 & 0.920 & 0.948 & 0.917 & 0.937 & 0.984 & 0.989 & 0.972 & 0.979 \\
\hline Cr\# & 0.134 & 0.122 & 0.118 & 0.182 & 0.191 & 0.191 & 0.201 & 0.210 & 0.160 & 0.159 & 0.236 & 0.250 & 0.246 & 0.233 \\
\hline Fe\# & 0.010 & 0.092 & 0.038 & 0.076 & 0.071 & 0.066 & 0.080 & 0.052 & 0.083 & 0.063 & 0.016 & 0.011 & 0.028 & 0.021 \\
\hline $\mathrm{Al}^{\mathrm{vi}}$ & 0.079 & 0.124 & 0.131 & 0.101 & 0.084 & 0.094 & 0.096 & 0.043 & 0.085 & 0.075 & 0.00 & 0.00 & 0.00 & 0.00 \\
\hline Wo & 48.20 & 47.68 & 27.64 & 47.74 & 47.55 & 49.25 & 44.91 & 46.23 & 45.76 & 44.53 & 33.27 & 33.97 & 33.89 & 32.45 \\
\hline En & 47.69 & 47.52 & 67.30 & 48.28 & 48.72 & 47.38 & 50.70 & 50.98 & 49.76 & 51.98 & 63.20 & 62.55 & 61.66 & 64.03 \\
\hline Fs & 4.11 & 4.80 & 5.06 & 3.98 & 3.73 & 3.37 & 4.39 & 2.79 & 4.48 & 3.49 & 3.53 & 3.48 & 4.45 & 3.52 \\
\hline
\end{tabular}

trusive rocks. Low $\mathrm{TiO}_{2}$ contents in clinopyroxene from the studied lherzolites generally reflect the removal of $\mathrm{TiO}_{2}$ during previous partial melting, and the very low Ti contents of the clinopyroxenes in harzburgites may imply that even more than one earlier partial melting event could have occurred.

\subsection{Chrome spinel}

Chrome spinel compositions of Kermanshah peridotites are listed in Tab. 5. These revealed a wide range of both $\mathrm{Cr} \#=[100 \times \mathrm{Cr} /(\mathrm{Cr}+\mathrm{Al})](17-80)$ and $\mathrm{Mg} \#=[100 \times \mathrm{Mg} /$ $(\mathrm{Mg}+\mathrm{Fe})]$ (47-79). The Cr\# gradually increase from lherzolites to harzburgites and dunites. Figure $7 d$ clearly shows that all chromian spinels plot along the line representing a $1: 1$ replacement of $\mathrm{Fe}\left(\mathrm{Cr}, \mathrm{Fe}^{3+}\right)_{2} \mathrm{O}_{4}$ (chromite end-member) by $\mathrm{MgAl}_{2} \mathrm{O}_{4}$ (spinel end-member). Nonetheless, chromian spinels from different rock types (harzburgites, dunites and wehrlites) show different proportions of the two end-members (Fig. 7d).
In the Cr\# of spinel vs. Fo content of olivine diagram (Fig. 7e), dunites and harzburgites fall in SSZ domain. Furthermore, all rock types fall into olivine-spinel mantle array (OSMA). This is regarded as the evidence for their residual origin, i.e. they form a trend which was likely caused by partial melting. As the Cr\# vs. Mg\# diagram of spinel shows, the value of Cr\# shows a counter relation with Mg\#. According to this trend (Fig. 7f), the studied peridotites show a wide variation in degree of partial melting, which is regarded as the main reason for heterogeneity within the upper mantle and melt-rock reaction.

\subsection{Serpentine}

Table 6 shows serpentine compositions of Kermanshah mantle peridotites. Due to different generations of serpentinization, serpentinite minerals are highly variable in their compositions. They contain (wt. \%): $\mathrm{SiO}_{2}=33.31-41.9$, $\mathrm{MgO}=30.11-47.40, \mathrm{Al}_{2} \mathrm{O}_{3}=0.00-10.42, \mathrm{FeO}=3.58-$ 8.57 and $\mathrm{Cr}_{2} \mathrm{O}_{3}=0.00-1.16$. 
Tab. 4 Continued

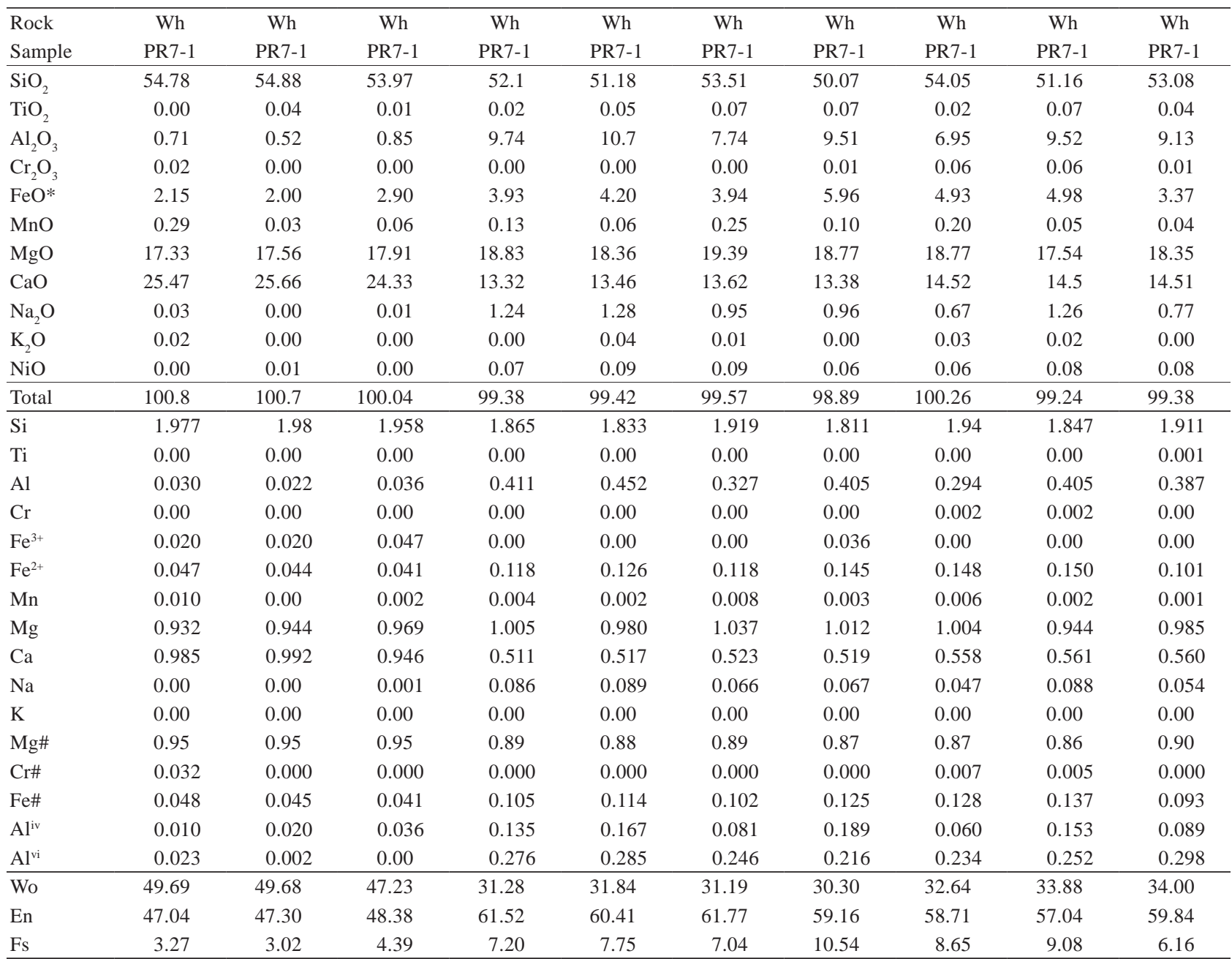

The $\mathrm{Fe}^{3+}$ and $\mathrm{Fe}^{2+}$ contents were calculated from the measured total $\mathrm{FeO}$ according to Droop (1987)

Hz: harzburgite, Lh: lherzolite

$\mathrm{Mg} \#=\mathrm{Mg} /\left(\mathrm{Mg}+\mathrm{Fe}^{2+}\right) ; \mathrm{Fe} \#=\mathrm{Fe}^{2+} /\left(\mathrm{Fe}^{2+}+\mathrm{Mg}\right) ; \mathrm{Cr} \#=\mathrm{Cr} /(\mathrm{Cr}+\mathrm{Al})$

Wo: wollastonite, En: enstatite, Fs: ferrosilite

According to Coleman (1971), there are two major petrological types of serpentinites. Pseudomorphic serpentinite, which consists dominantly of lizardite with minor concentrations of chrysotile, originates by retrograde replacement of olivine, orthopyroxene, and clinopyroxene with serpentines. The second type is represented by antigorite serpentinite, which is formed by the recrystallization of pseudomorphic serpentinites during progressive metamorphism.

In $\mathrm{MgO}$ vs. $\mathrm{SiO}_{2}$ diagram, all analyzed serpentine minerals are plotted in pseudomorphic serpentines field (Fig. 8a) which indicates that parent minerals were formed by retrogressive replacement of olivine, clinopyroxene and orthopyroxene with serpentines. Likewise, analyzed serpentine minerals in $\mathrm{Cr}_{2} \mathrm{O}_{3}$ vs. $\mathrm{Al}_{2} \mathrm{O}_{3}$ diagram fall in Ol-mesh field (Fig. 8b).

Based on Ashwal and Cairncross (1997), serpentine minerals can be divided into two sub-groups. The first sub-group is characterized by $\mathrm{Al}_{2} \mathrm{O}_{3}<1.5$ wt. \% (poor in $\mathrm{Al}$ ) and the second one displays marked enrichments of $\mathrm{Al}_{2} \mathrm{O}_{3}\left(\mathrm{Al}_{2} \mathrm{O}_{3}>7 \mathrm{wt}\right.$. \%). Analyzed serpentine mineral is mostly located in the first group.

\section{Discussion}

\subsection{Textures in selected ultramafic samples and their origin}

Although each petrogenetic process produces a specific mineral texture, some are not restricted to a particular process, and the other may rather reflect combined effects of several processes. Textures and bulk-rock compositions of Kermanshah ultramafic rocks in Harsin-Sahneh-Norabad and Miyanrahan areas provide clear evidence of cooling and decompression, partial 


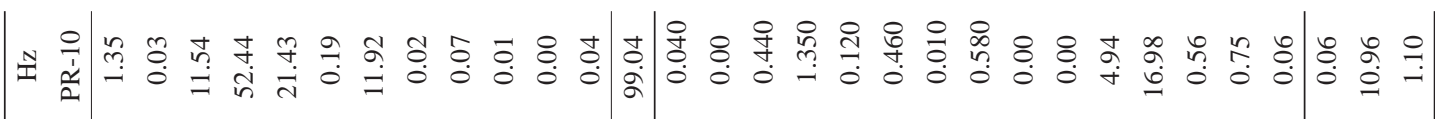

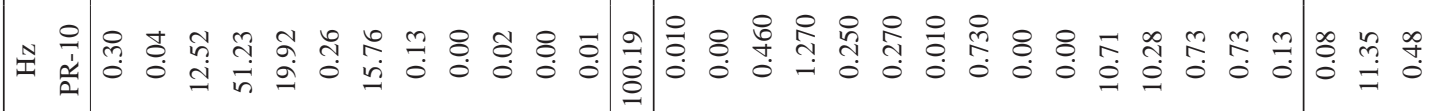
소 운

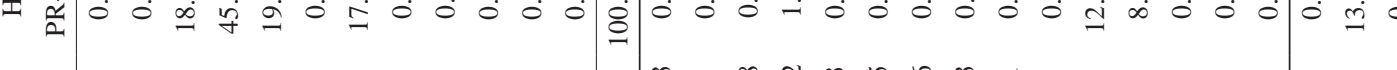

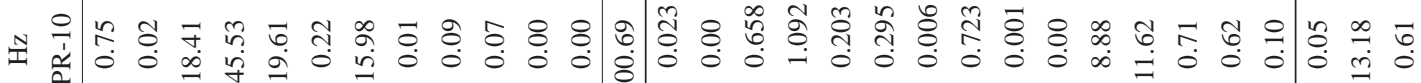
ผ

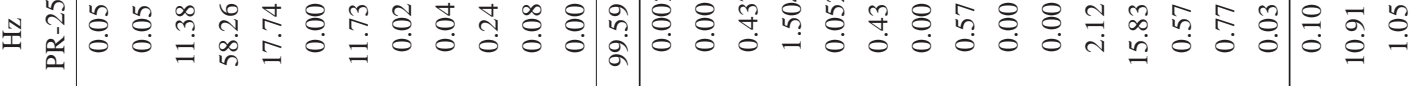
소 $\stackrel{2}{\sim}$ ㅇ I

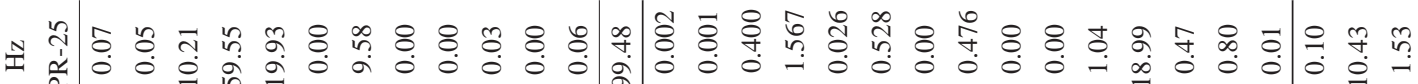
눙ํㅇ

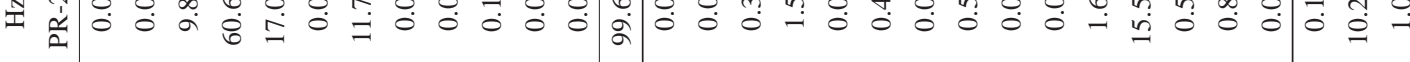

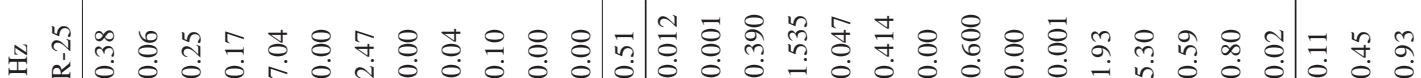

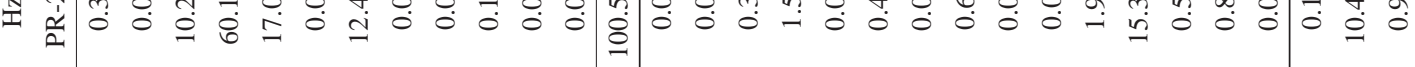
소 空 出

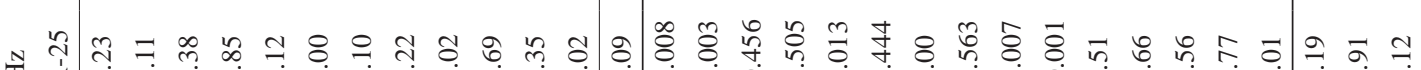

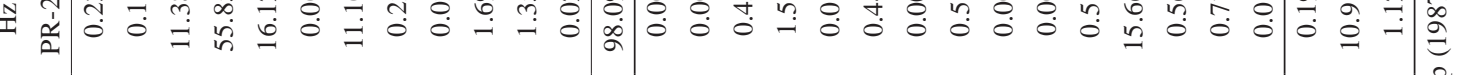

국 ஓ

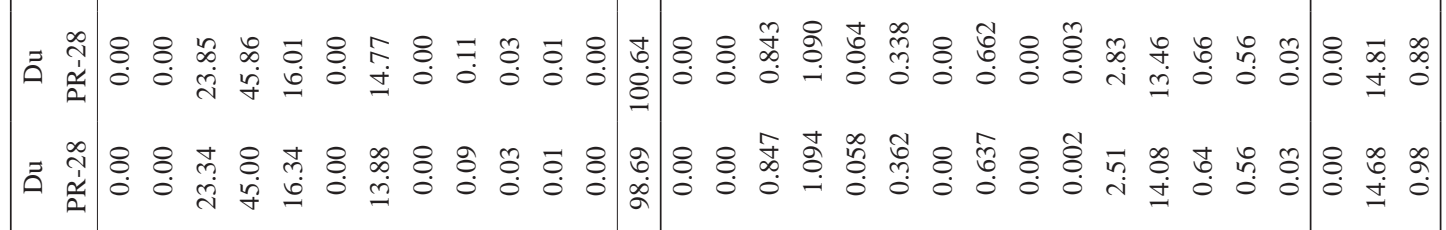
국 m

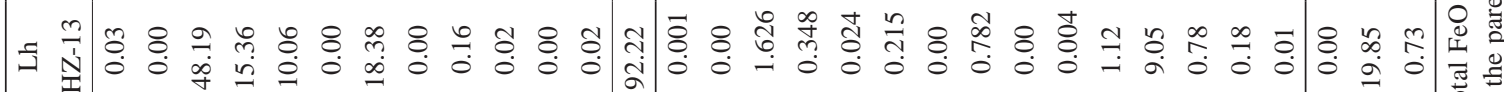
ป 言

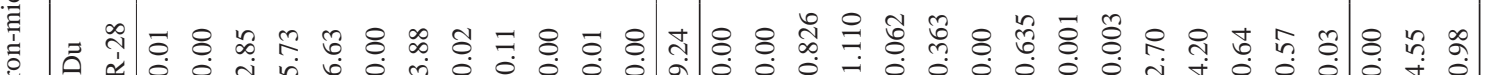

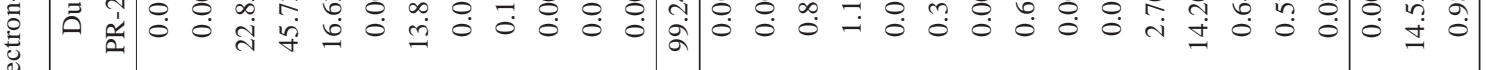

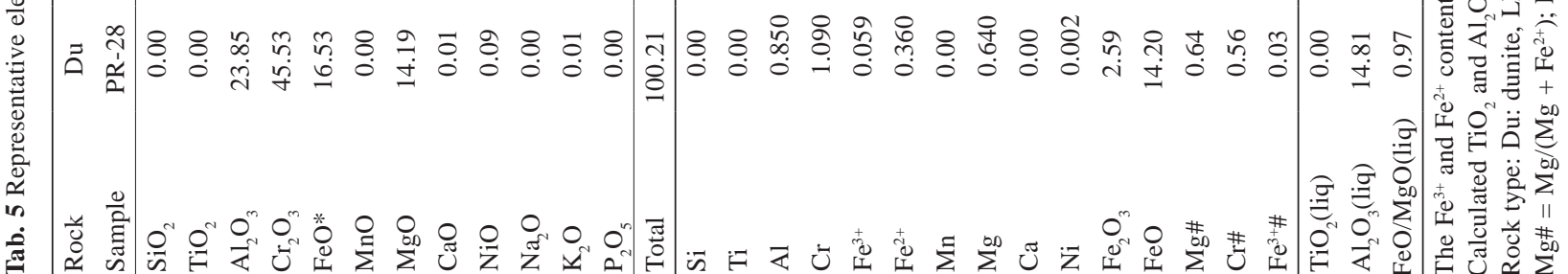




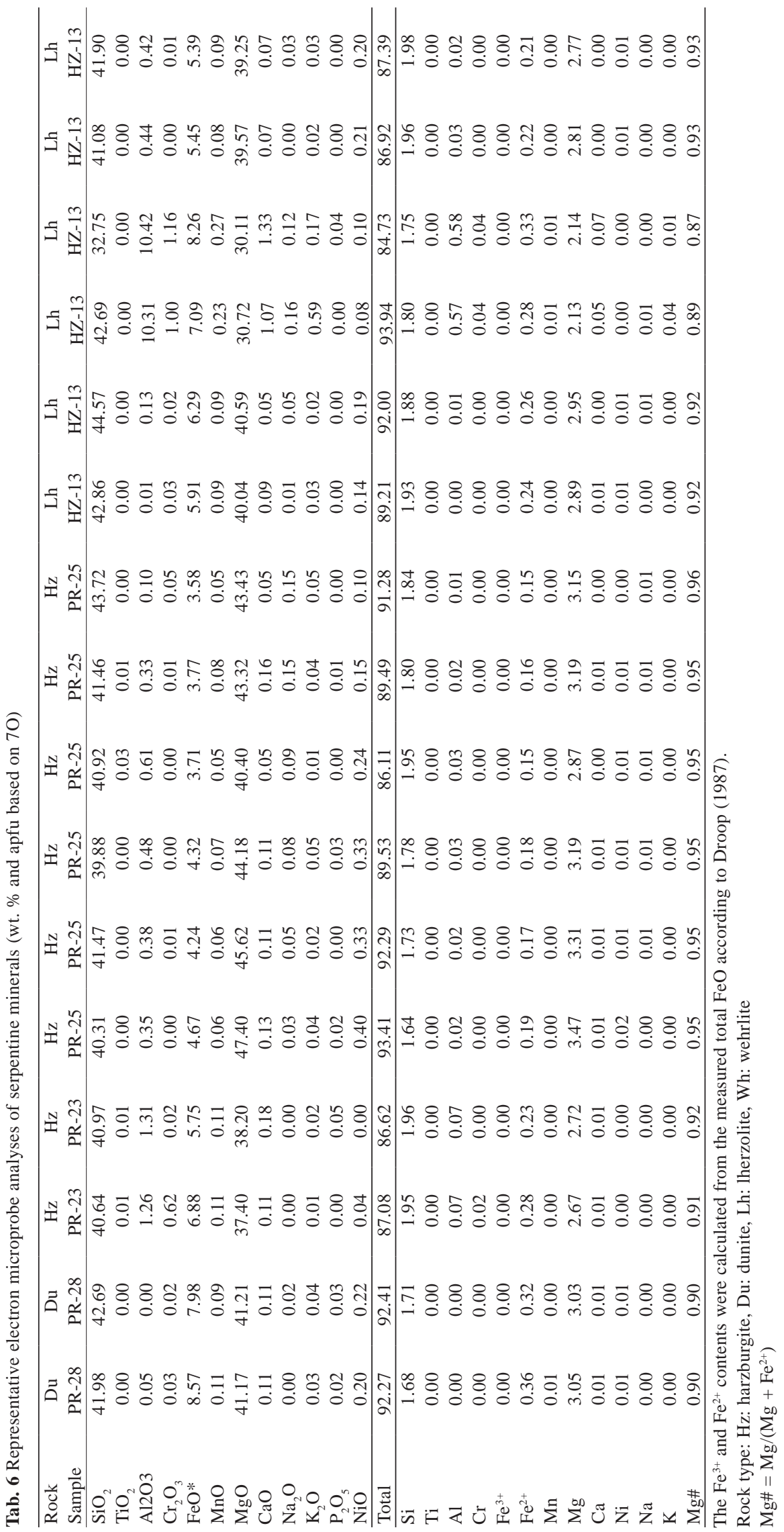

melting, and melt-rock reaction in lherzolites, harzburgites and dunites.

Exsolutions of clinopyroxene lamellae from orthopyroxene (Figs $4 \mathrm{~b}-\mathrm{c}$ and e) are one of the textures observed in this study. This type of texture is widespread in both abyssal and SSZ peridotites (Tamura and Arai 2006). Based on this paper, such exsolution is caused by a decrease in clinopyroxene solubility in orthopyroxene due to cooling and/ or decompression.

Some workers believe that such textures are produced by partial melting, though; a reaction followed by static recrystallization (Pearce et al. 2000), or by low-P partial melting of abyssal peridotites from which all the clinopyroxene has been removed (spinel stability field, Seyler et al. 2007; Li et al. 2015). Neumann (1991) suggested that exsolution lamellae of clinopyroxene in orthopyroxene probably represent relicts from an earlier orthopyroxene generation that gave rise to some of the olivine porphyroclasts by incongruent melting. This conclusion was supported by experimental studies showing that, in the presence of $\mathrm{H}_{2} \mathrm{O}$, orthopyroxene may melt incongruently at temperatures in excess of $1200{ }^{\circ} \mathrm{C}$ and pressures up to $20 \mathrm{kbars}$, leading to the formation of exsolved Cpx $+\mathrm{Spl}$ (Neumann 1991).

Therefore, given the presence of exsolution lamellae of clinopyroxene in orthopyroxene of the studied samples, it can be concluded that the formation of this texture could be the result of cooling and decompression of mantle peridotites produced by partial melting of primary or evolved mantle, or by earlier melt-rock reaction.

In the studied samples, the other remarkable texture represent embayed and chain-like spinel 

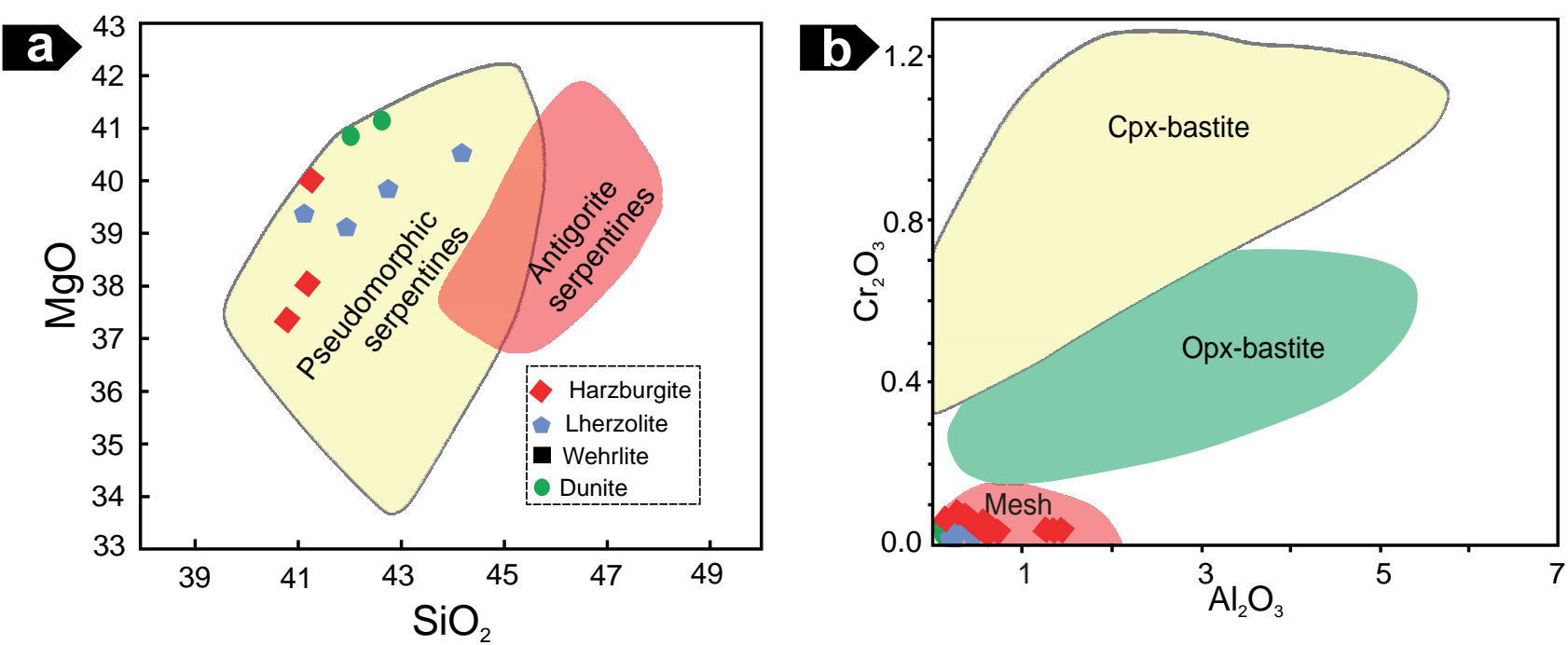

Fig. $8 \mathrm{MgO}$ vs. $\mathrm{SiO}_{2}$ diagram (a) and $\mathrm{Cr}_{2} \mathrm{O}_{3}$ vs. $\mathrm{Al}_{2} \mathrm{O}_{3}$ diagram (b) for the analyzed serpentine minerals (after Dungan 1979).

grains (Fig. 4d). Such embayed spinel grains are widely observed in many peridotites that have been related to partial melting (Saumur and Hattori 2013). However, others have suggested that this texture is formed by melt-rock reaction in the mantle (Bézard et al. 2011). O’Driscoll et al. (2010) suggested that such features could prove co-precipitation of $\mathrm{Cr}$-spinel with olivine.

\subsection{Melt/rock reaction}

Primary clinopyroxene can be an important $\mathrm{Cr}$ reservoir in upper mantle, commonly containing $1-2 \mathrm{wt}$. $\% \mathrm{Cr}_{2} \mathrm{O}_{3}$, i.e. contents comparable to those in orthopyroxene (Seyler et al. 2007).

Partial melting of Cr-bearing orthopyroxene releases Cr (Bézard et al. 2011):

$$
\mathrm{Cr}-\mathrm{Opx} \rightarrow \mathrm{Opx}_{(\text {Cr-depleted) }}+\mathrm{Cpx}+\mathrm{Spl}
$$

In harzburgite samples, high degrees of partial melting and melt-rock reaction lead to an increased abundance of Cr-spinel:

$$
\begin{aligned}
& \mathrm{Cpx}+\mathrm{Opx}+\mathrm{Spl} \rightarrow \text { melt } \\
& \mathrm{Cpx} / \mathrm{Opx} \rightarrow \mathrm{Cr}-\mathrm{Spl}+\mathrm{Ol}+\text { melt }
\end{aligned}
$$

Since dunites in Harsin-Sahneh-Norabad and Miyanrahan ophiolite complexes occur as small pods, they are interpreted as the result of melt-rock reaction rather than as residues of extensive partial melting. As melts migrate through the peridotite, clinopyroxene and orthopyroxene are dissolved and olivine precipitated (Fig. 4a) as illustrated by the reactions:

$$
\begin{aligned}
& \mathrm{Opx}+\mathrm{Cpx}+\text { melt }_{1} \rightarrow \mathrm{Ol}+\text { melt }_{2} \\
& \mathrm{Opx} \rightarrow \mathrm{Ol}+\text { melt }
\end{aligned}
$$

\subsection{Petrogenesis of ultramafic rocks - mineral chemistry approach}

Vanadium can be a sensitive indicator of oxygen fugacity in residual mantle rocks, and in general, SSZ peridotites have low V contents (Pearce et al. 2000). Given the relatively low $\mathrm{V}$ contents in the Kermanshah peridotites, In a plot of $\mathrm{V}$ vs. $\mathrm{Yb}$ (Fig. 5b) the samples fall close to the QFM buffer (mostly between QFM and QFM + 1), suggesting a SSZ affinity (Pearce et al. 2000).

In a $\mathrm{TiO}_{2}$ vs. $\mathrm{Al}_{2} \mathrm{O}_{3}$ plot (Fig. 9a), chrome spinels of the Kermanshah peridotites show an arc affinity. However, forearc regions may contain both SSZ and abyssal peridotites, although the former are typically dominant (Pearce et al. 2000).

In addition, chrome spinels in SSZ peridotites are characterized by $\mathrm{Cr} \#$ values often significantly higher (38-80) than abyssal peridotites (38-58). Elevated Cr\# values of selected peridotite samples (17-80, on average 60 - Tab. 5), can also reflect higher degrees of partial melting or much more extensive melt-rock reaction (Arai 1994).

Most pyroxenes in SSZ peridotites are characterized by extremely low minor-element (Al, Ti) contents compared to the abyssal peridotites, but generally have higher Mg\# (Choi et al. 2008). Average Mg\# in Kermanshah orthopyroxenes and clinopyroxenes are 0.95 and 0.93 respectively (Tabs 3 and 4). Accordingly, in the $\mathrm{Al}_{2} \mathrm{O}_{3}$ vs. $\mathrm{Cr}_{2} \mathrm{O}_{3}$ diagram (Fig. 9b), the chromian spinels from the studied peridotites fall into the olivine-spinel mantle array (OSMA). Likewise Fig. 7e-f, this diagram indicates that Harsin-Sahneh-Norabad and Miyanrahan mantle peridotites were generated in volcanic-arc environment.

Experimental studies confirm that the $\mathrm{Al}_{2} \mathrm{O}_{3}$ and $\mathrm{TiO}_{2}$ contents, as well as $\mathrm{FeO} / \mathrm{MgO}$ ratios in chromian spinel are directly related to those of the parental melt (Rol- 

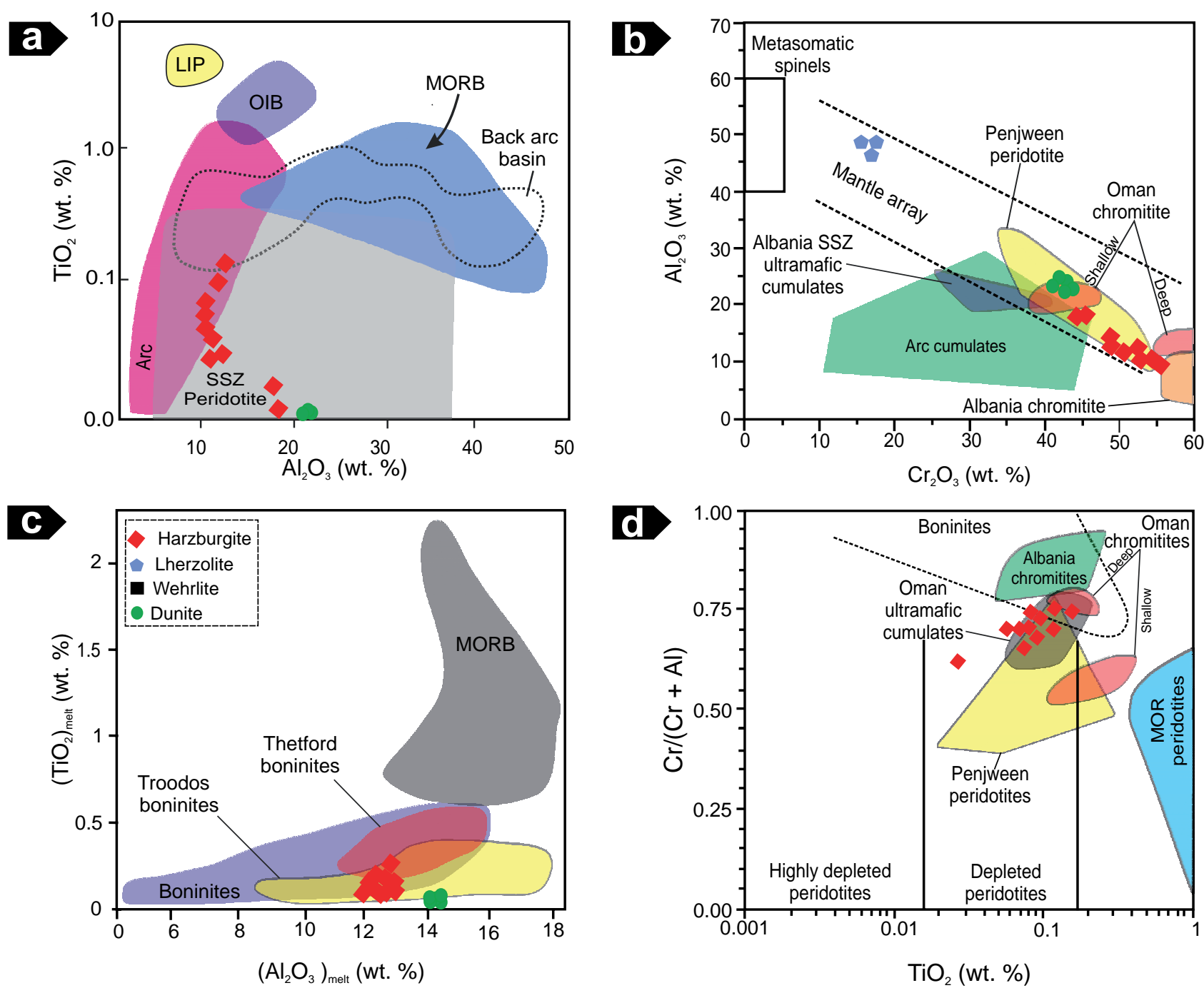

Fig. 9 Mineral chemistry of chromian spinels in mantle peridotites from Kermanshah ophiolites: a - TiO vs. $\mathrm{Al}_{2} \mathrm{O}_{3}$ diagram (after Dick and Bullen 1984). Compositional fields for spinels in MORB and SSZ (Dick and Bullen 1984), Arc, OIB, LIP and back-arc basin (Kamenetsky et al. 2001); b $-\mathrm{Al}_{2} \mathrm{O}_{3}$ vs. $\mathrm{Cr}_{2} \mathrm{O}_{3}$ diagram (after Franz and Wirth 2000). Compositional fields for spinels in Oman chromitites (Rollinson 2008), Penjween peridotites (Aswad et al. 2011), and Albania ophiolites (Saccani et al. 2011) are shown for comparison; c - TiO ${ }_{2}$ melt vs. $\mathrm{Al}_{2} \mathrm{O}_{3}$ melt calculated in equilibrium with chromite. Fields for boninites (Kamenetsky et al. 2001), MORB, Troodos boninites and Thetford boninites (Page and Barnes 2009) are shown for comparison; $\mathbf{d}-\mathrm{Cr} /(\mathrm{Cr}+\mathrm{Al}) \mathrm{vs}$. $\mathrm{TiO}_{2}$ diagram; compositional fields for spinels in abyssal (MOR) peridotites (Dick and Bullen 1984), Oman chromitites (Rollinson 2008), Penjween peridotites (Aswad et al. 2011) and Albania ophiolites (Saccani et al. 2011) are shown for comparison. Abbreviations: MORB - mid-ocean ridge basalt; OIB - ocean-island basalt; LIP - large igneous province, Arc - island-arc magma, SSZ - supra-subduction zone.

linson 2008). According to Maurel and Maurel (1982), $\mathrm{Al}_{2} \mathrm{O}_{3}$ content of the parental melt can be calculated as:

$$
\left.\mathrm{Al}_{2} \mathrm{O}_{3} \text { (wt. \%) }\right)_{\text {in Cr-Spl }}=0.035 \times \mathrm{Al}_{2} \mathrm{O}_{3} \text { (wt. \%) } \text { in Parental Melt }^{2.42}
$$

The $\mathrm{Al}_{2} \mathrm{O}_{3}$ contents of the parental melt calculated by this formula range from 10 to 14 wt. \% for the studied harzburgites and dunites (Tab. 5). Such values are consistent with boninitic or island-arc tholeiites (IAT) melts, which typically contain 10-14 wt. \% and 12-16 wt. \% $\mathrm{Al}_{2} \mathrm{O}_{3}$, respectively (Dilek and Thy 2009).

Rollinson (2008) proposed a formula relating $\mathrm{TiO}_{2}$ content in chromian spinel and parental melt:

$$
\left.\mathrm{TiO}_{2} \text { (wt. \%) }\right)_{\text {melt }}=1.0963 \times \mathrm{TiO}_{2} \text { (wt. \%) }{ }_{\mathrm{Cr}-\mathrm{Spl}}^{0.7863}
$$

Low calculated $\mathrm{TiO}_{2}$ contents (less than 0.25 wt. $\%$-Tab. 5) also suggest a boninitic-type parental melt. Indeed, the calculated $\mathrm{Al}_{2} \mathrm{O}_{3}$ and $\mathrm{TiO}_{2}$ contents fall into the field of boninitic rocks (Fig. 9c), overlapping with Troodos and Thetford boninites fields.

The $\mathrm{FeO} / \mathrm{MgO}$ ratio in the parental melt has also been calculated using the empirical formula of Augé (1987):

$$
\begin{aligned}
& \ln (\mathrm{FeO} / \mathrm{MgO})_{\mathrm{Cr}-\mathrm{Spl}}=0.47-1.07 \mathrm{Y}_{\mathrm{Cr}-\mathrm{Spl}}^{\mathrm{Al}}+0.64 \mathrm{Y}_{\mathrm{Cr}-\mathrm{Spl}}^{\mathrm{Fe}+}+ \\
& \ln (\mathrm{FeO} / \mathrm{MgO})_{\mathrm{melt}}
\end{aligned}
$$


where: $\mathrm{YFe}^{3+}{ }_{\mathrm{Cr}-\mathrm{Spl}}=\mathrm{Fe}^{3+} /\left(\mathrm{Al}+\mathrm{Cr}+\mathrm{Fe}^{3+}\right), \mathrm{Y}_{\mathrm{Cr}}^{\mathrm{Al}-\mathrm{Spl}}=\mathrm{Al} /$ $\left(\mathrm{Al}+\mathrm{Cr}+\mathrm{Fe}^{3+}\right)$. Calculated $\mathrm{FeO} / \mathrm{MgO}$ ratio for parental melts varies from 0.61 to 1.12 (Tab. 5) which is slightly higher than what is expected for primary boninitic liquids (0.5-0.8: Dilek and Thy 2009).

However, most of the calculated $\mathrm{FeO} / \mathrm{MgO}$ ratios of parental melts (Tab. 5) are comparable with those in boninites from the Oman Ophiolite (0.7-1.2: Rollinson 2008). Still, it should be noted that subsolidus re-equilibration may significantly change $\mathrm{FeO} / \mathrm{MgO}$ ratio in chromian spinels (Augé 1987) and this could explain some of our comparatively high calculated $\mathrm{FeO} / \mathrm{MgO}$ ratios.

In the $\mathrm{Cr} \#$ vs. $\mathrm{TiO}_{2}$ diagram (Fig. 9d), the Kermanshah peridotites classify as depleted peridotites, resembling Oman ultramafic cumulates and Penjween peridotites. In summary, the findings from Fig. 9 indicate that chemistries of the chrome spinels in the Sahneh, HarsinNorabad and Miyanrahan peridotites are compatible with a genesis in a subduction setting from boninitic or primitive arc magmas, such as picrites or island-arc tholeiites.

\section{Geodynamic synthesis}

The ophiolites from the Zagros Suture Zone are subdivided into two parallel units, Outer Zagros Ophiolitic Belt and Inner Zagros Ophiolitic Belt. The latter represent remnants of southern branch of the Neo-Tethyan Ocean in Iran, outcropping in Kermanshah Province, western Iran (Braud 1987).

Since the pole of rotation for Arabia- Eurasia convergence lies in Eastern Mediterranean, the convergence is oblique $\left(60^{\circ}\right)$ and its rate increases eastward along Zagros Orogenic Belt, from $\sim 1.5-1.8 \mathrm{~cm} /$ year in the NW to $\sim 2.8$ $\mathrm{cm} /$ year in the SE (Vergés et al. 2011). Tomography data indicate that the Arabian lithosphere underlays Zagros and Sanandaj-Sirjan, dipping $c .50^{\circ}$ to the NE (Agard et al. 2011). This slab is subducted beneath NW Zagros and underthrusted beneath central Zagros. After the initiation of continental underthrusting in Zagros, the average Arabia Plate velocity decreased by $\sim 30 \%$, from $\sim 3.1$ to $\sim 2.4$ $\mathrm{cm} / \mathrm{yr}$ (Reilinger and McClusky 2011). Reduction of plate convergence in north, south, and central Zagros was an important driving force for the slab break-off. Moreover, slab break-off has been followed by slab rollback and Tethyan slab retreat. Mouthereau et al. (2012) suggested that the Bisotun Block, a buoyant continental segment is present in north-western but absent in central Zagros; its buoyancy likely enhanced the slab retreat. The initiation of Arabia continental plate underthrusting beneath the Sanandaj-Sirjan Zone was another important force driving the Tethyan slab retreat (Mouthereau et al. 2012).

Studies of ophiolite complexes in the Zagros Orogen indicated that most of the Zagros ophiolites were gener- ated in an intra-oceanic arc environment (Saccani et al. 2013). These studies concluded that during intra-oceanic subduction, an immature island arc developed before the ocean closure. Subducting slab collapse during this phase led to the large-scale extension in the overriding oceanic plate and thereby to the generation of supra-subduction ophiolites.

Wrobel-Daveau et al. (2010) suggested that the Harsin-Sahneh ophiolites were a part of a rifted basin at the ocean-continent transition zone, generated in the southern Neo-Tethyan Ocean. Saccani et al. (2013) reported that these ophiolites, irrespective to the age of different units, have OIB to EMORB affinity. Accordingly, these authors interpreted the entire Harsin-Sahneh ophiolites as an accreted oceanic basin under the influence of a mantle plume situated at the ocean-continent transition zone of the southern margin of the Tethyan Ocean.

Two models have been proposed for the genesis of boninites: (1) subduction initiation (and forearc extension) model and (2) subduction initiation and subsequent back-arc spreading model. Xia et al. (2012) described two chemical subgroups of boninites as forearc-related and back-arc basin-related. The compositions of the of forearc boninites reflect the effects of varying melts/fluids compositions and heterogeneous metasomatism in the mantle wedge, showing, within a single arc system, a systematic decrease in slab influence with increasing distance from the trench. In contrast, back-arc basin-related boninites are characterized by major involvement of mantle wedge, but the role for slab-derived components is limited due to a higher distance from the slab. Therefore, back-arc basin-related boninites generally display MORB-like chemistry. Based on the lithological variations along NE-SW trending geographical positions, we propose that forearc-related boninitic parental magmas largely interacted with southern Kermanshah mantle peridotites. The likely sequence of tectonic events leading to the formation of Kermanshah arc then was as follows:

(i) Sanandaj-Sirjan continental arc magmatism had ended in the Late Cretaceous. It may be that the Southern Neo-Tethyan oceanic crust broke off at this time, subducted beneath itself and developed arc magmatism in the Kermanshah region. As a result, Neo-Tethyan oceanic crust subduction beneath the arc stopped at this time.

(ii) In the Late Cretaceous, magmatic-arc related rocks developed from Kermanshah ophiolites. In this geodynamic setting, Kermanshah ultramafic rocks closer to the trench were largely affected by percolating forearc-related hydrous boninitic melts.

Whitechurch et al. (2013) work on sedimentary rocks in Kamyaran and to the north of Harsin-Sahneh region indicated that the subduction-related magmatism has been active mainly between Palaeocene and Eocene. This period of arc-related magmatism in the Kermanshah 
region roughly coincided with magmatic quiescence in the Sanandaj-Sirjan Zone . By the end of short-lived Kermanshah magmatism in Middle Eocene, continental arc magmatism resumed and shifted from Sanandaj-Sirjan Arc to the Urumieh-Dokhtar Arc.

\section{Conclusions}

The main conclusions from this study are as follows:

1) Mantle restites in Kermanshah ophiolites are characterized by very low concentrations of REE and incompatible elements. Such geochemical features, typically observed in many subduction-related ophiolites, as well as in modern intra-oceanic subduction settings, are interpreted as the result of boninitic-type melt removal. In addition, the significant LREE/MREE enrichment suggests that the studied rocks represent mantle previously enriched in LILE and LREE by subduction-derived hydrous fluids.

2) Calculated $\mathrm{Al}_{2} \mathrm{O}_{3}$ contents and $\mathrm{Mg} \#$ values in the melt in equilibrium with chromian spinel and olivine are consistent with either boninitic or igneous-arc tholeiitic melts. Nonetheless, the very low ( $<0.25$ wt. \%) $\mathrm{TiO}_{2}$ calculated for the parental melt in equilibrium with chromian spinel are only consistent with boninitic-type parental melts.

3) Accordingly, whole-rock composition suggests that Harsin-Sahneh-Norabad and Miyanrahan ultramafic rocks may represent the residual mantle after extraction of $13-22 \%$ of boninitic-type melts.

4) Mineral and whole-rock chemistry clearly indicate that Harsin-Sahneh-Norabad and Miyanrahan ultramafic rocks record an episode of boninitic magmatism that occurred within the southern Neo-Tethys Ocean in Late Cretaceous. Boninitic melts in Kermanshah Ophiolites were formed by partial melting of depleted peridotite, a residue after MORB-type melt extraction. It is therefore suggested that this boninitic magmatism was generated in forearc sector of a short-lived intra-oceanic arc that was located south of the "Andean-type" subduction below the Sanandaj-Sirjan continental margin.

5) The Late Cretaceous subduction of southern NeoTethyan Ocean beneath itself led to the cessation of subduction beneath the Sanandaj-Sirjan Zone. The quiescent period of magmatism in the Sanandaj-Sirjan Zone roughly coincided with the arc-related magmatism in Kermanshah region. The resumption of subduction generated arc-related magmatic rocks in the Harsin-Sahneh-Norabad and Miyanrahan regions and Sonqor-Baneh and Hamedan-Tabriz volcanic belts. The second stage of magmatism occurred after Kermanshah Ophiolite obduction when the igneous activity shifted from Sanandaj-Sirjan Arc to the Urumieh-Dokhtar Arc.
Acknowledgements. The authors wish to thank V. Janoušek, Editor in chief of Journal of Geosciences, E. Jelínek, handling editor, and two anonymous reviewers who critically reviewed the manuscript and made valuable suggestions for its improvement.

\section{References}

Agard P, Omrani J, Jolivet L, Whitechurch H, Vrielynck B, Spakman W, Monie P, Meyer B, Wortel R (2011) Zagros orogeny: a subduction-dominated process. Geol Mag 148: 692-725

Allahyari K, Saccani E, Rahimzadeh B, Zeda O (2014) Mineral chemistry and petrology of highly magnesian ultramafic cumulates from the Sarve-Abad (Sawlava) ophiolites (Kurdistan, NW Iran): new evidence for boninitic magmatism in intra-oceanic forearc setting in the Neo-Tethys between Arabia and Iran. J Asian Earth Sci 79: 312-328

Ao S, Xiao W, Khalatbari Jafari M, Talebian M, Chen L, WAN B, Ji W, ZHANG Z (2016) U-Pb zircon ages, field geology and geochemistry of the Kermanshah Ophiolite (Iran): from continental rifting at $79 \mathrm{Ma}$ to oceanic core complex at ca. $36 \mathrm{Ma}$ in the southern Neo-Tethys. Gondwana Res 3: 305-318

ARAI S (1994) Characterisation of spinel peridotites by olivine-spinel compositional relationships: review and interpretation. Chem Geol 113: 191-204

AsHWAL L D, CAIRnCRoss B (1997) Mineralogy and origin of stichtite in chromite bearing serpentinites. Contrib Mineral Petrol 127: 75-86

Aswad KJA, AzIz NRH, Koyi HA (2011) Cr-spinel compositions in serpentinites and their implications for the petrotectonic history of the Zagros Suture Zone, Kurdistan Region, Iraq. Geol Mag 148: 802-818

Augé T (1987) Chromite deposits in the northern Oman Ophiolite: mineralogical constraints. Miner Depos 22: 1-10

BARnes SJ, RoEDER PL (2001) The range of spinel compositions in terrestrial mafic and ultramafic rocks. J Petrol 42: 2279-2302

Bézard R, Hébert R, Wang C, Dostal J, Dai J, Zhong $H$ (2011) Petrology and geochemistry of the Xiugugabu ophiolitic massif, western Yarlung Zangbo suture zone, Tibet. Lithos 125: 347-367

BRAUD J (1987) Geological map of Kermanshah. 1 : 250.000 scale. Geological Survey of Iran, Tehran

CAMERon WE (1985) Petrology and origin of primitive lavas from the Troodos Ophiolite, Cyprus. Contrib Mineral Petrol 89: 239-255

Choi SH, Shervais JW, Mukasa SB (2008) Supra-subduction and abyssal mantle peridotites of the Coast Range Ophiolite. Contrib Mineral Petrol 156: 551-576 
Coleman RG (1971) Plate tectonic emplacement of upper mantle peridotite along continental edges. J Geophys Res 76: 1212-1222

Deer WA, Howie R A, Zussman J (1992) An Introduction to the Rock Forming Minerals. Wiley, New York, pp 1-696

Dick HJB, Bullen T (1984) Chromian spinel as a petrogenetic indicator in abyssal and alpine type peridotites and spatially associated lavas. Contrib Mineral Petrol 86: 54-76

Dilek Y, FuRnes H (2011) Ophiolite genesis and global tectonics: geochemical and tectonic fingerprinting of ancient oceanic lithosphere. Geol Soc Am Bull 123: 387-411

DiLEK Y, THY P (2009) Island arc tholeiite to boninitic melt evolution of the Cretaceous Kizildag (Turkey) Ophiolite: model for multi-stage early arc-forearc magmatism in Tethyan subduction factories. Lithos 113: 68-87

Droop GTR (1987) A general equation for estimating $\mathrm{Fe}^{3+}$ concentrations in ferromagnesian silicates and oxides from microprobe analyses, using stoichiometric criteria. Mineral Mag 51: 431-435

Dungan MA (1979) A microprobe study of antigorite and some serpentine pseudomorphs. Canad Mineral 17: 711-784

Franz L, Wirth R (2000) Spinel inclusions in olivine of peridotite xenoliths from TUBAF seamount (Bismarck Archipelago/Papua New Guinea): evidence for the thermal and tectonic evolution of the oceanic lithosphere. Contrib Mineral Petrol 140: 283-295

Harnois L, Trottier J, Morency M (1990) Rare earth element geochemistry of Thetford Mines Ophiolite Complex, Northern Appalachians, Canada. Contrib Mineral Petrol 105: 433-445

Kamenetsky VS, CraWford AJ, MefFre S (2001) Factors controlling chemistry of magmatic spinel: an empirical study of associated olivine, Cr-spinel and melt inclusions from primitive rocks. J Petrol 42: 655-671

Li XP, Chen HK, Wang ZL, WANG LJ, YANG JS, Robinson P (2015) Spinel peridotite, olivine websterite and the textural evolution of the Purang Ophiolite Complex, western Tibet. J Asian Earth Sci 110: 55-71

Maurel C, Maurel P (1982) Etude expérimental de la distribution de l'aluminium entre bain silicate basique et spinelle chromifère. Implications pétrogenetiques: teneur en chrome des spinelles. Bull Mineral 105:197-202

мовімото N (1989) Nomenclature of pyroxenes. Canad Mineral 27: 143-156

Mouthereau F, Lacombe O, Vergés J (2012) Building the Zagros collisional orogen: timing, strain distribution and the dynamics of Arabia/Eurasia plate convergence. Tectonophysics 532-535: 27-60

NeUmann ER (1991) Ultramafic and mafic xenoliths from Hierro, Canary Islands: evidence for melt infiltration in the upper mantle. Contrib Mineral Petrol 106: 236-252
O'Driscoll B, Emeleus CH, Donaldson CH, Daly JS (2010) Cr-spinel seam petrogenesis in the Rum layered suite, NW Scotland: cumulate assimilation and in situ crystallization in a deforming crystal mush. J Petrol 51: 1171-1201

Page P, Barnes SJ (2009) Using trace elements in chromites to constrain the origin of podiform chromitites in the Thetford Mines Ophiolite, Québec, Canada. Econ Geol 104: 997-1018

Parkinson IJ, Pearce JA (1998) Peridotites from the IzuBonin-Mariana forearc (ODP Leg 125): evidence for mantle melting and melt-mantle interaction in a suprasubduction zone setting. J Petrol 39: 1577-1618

Pearce JA, Norry MJ (1979) Petrogenetic implications of $\mathrm{Ti}, \mathrm{Zr}, \mathrm{Y}$, and Nb variations in volcanic rocks. Contrib Mineral Petrol 69: 33-47

Pearce JA, Barker PF, Edwards S, Parkinson IJ, Leat PT (2000) Geochemistry and tectonic significance of peridotites from the South Sandwich arc-basin system, South Atlantic. Contrib Mineral Petrol 139: 36-53

Presnall DC, Hoover JD (1987) High pressure phase equilibrium constraints on the origin of mid-ocean ridge basalts. In: Mrsen BO (ed) Magmatic Processes: Physicochemical Principles. The Geochemical Society Special Papers 1: 75-89

Rafia R, Shahidi A (1999) Geological map of Mianrahan, 1:100.000 scale. Geological Survey of Iran, Tehran

Rajabzadeh MA, Nazari DehKordi T, Caran S (2013) Mineralogy, geochemistry and geotectonic significance of mantle peridotites with high-Cr chromitites in the Neyriz Ophiolite from the outer Zagros ophiolite belts, Iran. J Asian Earth Sci 78: 1-15

ReILINGER R, McClusky S (2011) Nubia-Arabia-Eurasia plate motions and the dynamics of Mediterranean and Middle East tectonics. Geophys J Int 186: 971-979

Rollinson H (2008) The geochemistry of mantle chromitites from the northern part of the Oman Ophiolite: inferred parental melt compositions. Contrib Mineral Petrol 156: 273-288

Saccani E, Beccaluva L, Photiades A, Zeda O (2011) Petrogenesis and tectonomagmatic significance of basalts and mantle peridotites from the Albanian-Greek ophiolites and sub-ophiolitic mélanges. New constraints for the Triassic-Jurassic evolution of the Neo-Tethys in the Dinaride sector. Lithos 124: 227-242

Saccani E, Allahyari K, Beccaluva L, Bianchini G (2013) Geochemistry and petrology of the Kermanshah ophiolites (Iran): implication for the interaction between passive rifting, oceanic accretion, and OIB-type components in the Southern Neo-Tethys Ocean. Gondwana Res 24: 392-411

Saumur BM, HatTori K (2013) Zoned Cr-spinel and ferritchromite alteration in forearc mantle serpentinites of the Rio San Juan Complex, Dominican Republic. Mineral Mag 77: 117-136 
Seyler M, Lorand JP, Dick HJB, Drouin M (2007) Pervasive melt percolation reactions in ultra-depleted refractory harzburgites at the Mid-Atlantic Ridge. Contrib Mineral Petrol 153: 303-319

Shahidi M, NAZARI H (1997) Geological map of Harsin, 1:100.000 scale. Geological Survey of Iran, Tehran

StöcKLIN J (1968) Structural history and tectonics of Iran; a review. AAPG Bull 52: 1229-1258

Sun SS, McDonough WF (1989) Chemical and isotopic systematics of oceanic basalts: implications for mantle composition and processes. In: SAUNDERS AD, NORRY MJ (eds) Magmatism in the Ocean Basins. Geological Society of London Special Publications 42: 313-345

TAmura A, Arai S (2006) Harzburgite-dunite-orthopyroxenite suite as a record of supra-subduction zone setting for the Oman Ophiolite mantle. Lithos 90: 43-56

Vergés J, Saura E, Casciello E, Fernández M, VilLASEÑor A, JimÉnEZ-Munt I, GARCíA-CASTEllanos D (2011) Crustal-scale cross-section across the NW Zagros Belt: implications for the Arabian margin reconstruction. In: Lacombe O, Grasemann B, Simpson G (eds) Geodynamic Evolution of the Zagros. Geol Mag 148: 739-761
Whitechurch H, Omrani J, Agard P, Humbert F, MonTigny R, Jolivet L (2013) Evidence for PaleoceneEocene evolution of the foot of the Eurasian margin (Kermanshah Ophiolite, SW Iran) from back-arc to arc: implications for regional geodynamics and obduction. Lithos 182-183: 11-32

Workman RK, HART SR (2005) Major and trace element composition of the depleted MORB mantle (DMM). Earth Planet Sci Lett 231: 53-72

Wrobel-Daveau JC, Ringenbach JC, Tavakoli S, Ruiz GMH, Masse P, DE LAmotte DF (2010) Evidence for mantle exhumation along the Arabian margin in the Zagros (Kermanshah area, Iran). Arabian J Geosci 3: 499-513

XIA X, Song S, Niu Y (2012) Tholeiite-boninite terrane in the North Qilian suture zone: implications for subduction initiation and back-arc basin development. Chem Geol 328: 259-277

Zarei Sahamieh R, Moradpour A (2015) Geochemistry and petrology of Harsin-Sahneh Ophiolitic Complex (NE of Kermanshah - west of Iran) an evidence of southern Neo-Tethys Ocean tectonic. Arabian J Geosci 8: 8347-836 